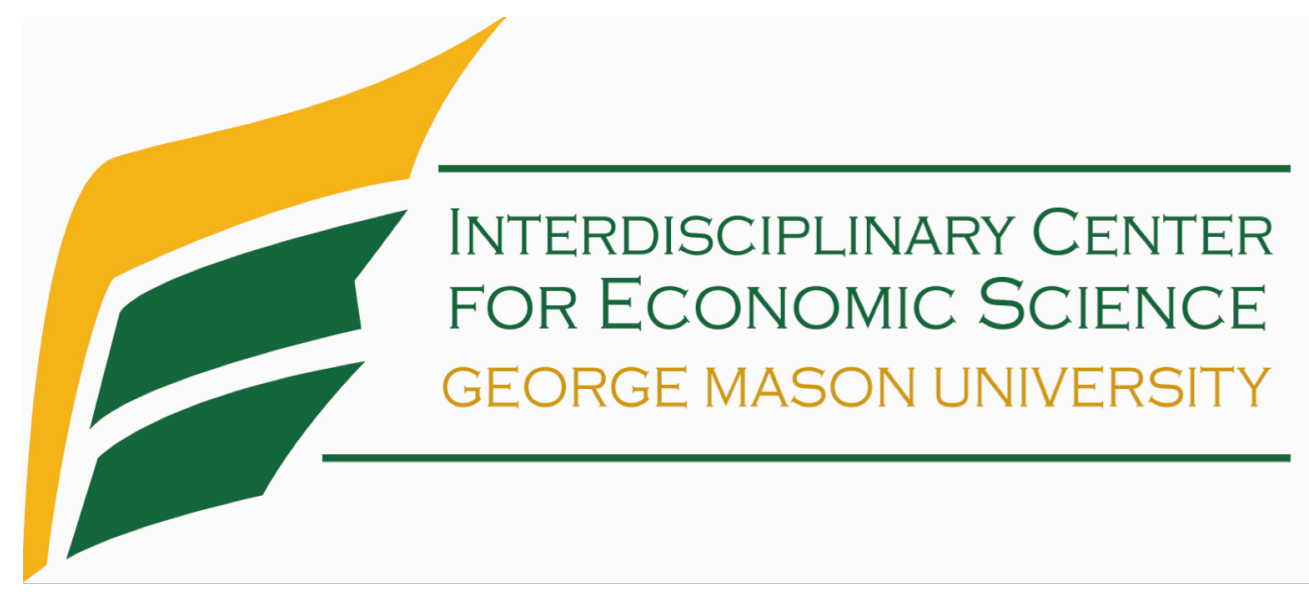

\title{
Delegating Altruism: Toward an Understanding of Agency in Charitable Giving
}

\author{
Luigi Butera and Daniel Houser
}

June 2016

Discussion Paper

Interdisciplinary Center for Economic Science

4400 University Drive, MSN 1B2, Fairfax, VA 22030

Tel: +1-703-993-4719 Fax: +1-703-993-4851

ICES Website: $h$ ttp://ices.gmu.edu

ICES RePEc Archive Online at: http://edirc.repec.org/data/icgmuus.html 


\title{
Delegating altruism: Toward an understanding of agency in charitable giving*
}

\author{
Luigi Butera ${ }^{\dagger}$
}

Daniel E. Houser

May 23, 2016

\begin{abstract}
Philanthropy, and particularly ensuring that ones giving is effective, can require substantial time and effort. One way to reduce these costs, and thus encourage greater giving, could be to encourage delegation of giving decisions to better-informed others. At the same time, because it involves a loss of agency, delegating these decisions may produce less warm-glow and thus reduce one's charitable impulse. Unfortunately, the importance of agency in charitable decisions remains largely unexplored. In this paper, using a laboratory experiment with real donations, we shed light on this issue. Our main finding is that agency, while it does correlate with self-reported warm-glow, nevertheless seems to play a small role in encouraging giving. In particular, people do not reduce donations when giving decisions are made by (costly) algorithms that guarantee efficient recipients. Moreover, we find participating in giving groups - a weaker form of delegation - is also effective in that they are appealing to donors who would not otherwise make informed donations, and thus improves overall effective giving. Our results suggest that one path to promoting effective giving may be to create institutions that facilitate delegated generosity.
\end{abstract}

JEL-Classification: C9, D64, D71

Keywords: Altruism, Laboratory Experiment, Agency, Charitable Giving.

${ }^{*}$ We are grateful to Björn Bartling, Martin Kocher, Silvana Krasteva, John List, Fatemeh Momeni, Matthias Sutter, and Marie Claire Villeval for helpful comments. We gratefully acknowledge financial support by the John Templeton Foundation and the Science of Philanthropy Initiative. For helpful comments we thank participants at the Science of Philanthropy Initiative annual conference 2015, ESA North America Meetings 2015, and seminar participants at the University of Chicago. Shuwen Li provided outstanding research assistance.

${ }^{\dagger}$ Becker Friedman Institute for Research in Economics (BFI), Department of Economics, The University of Chicago. Email: lbutera@uchicago.edu - - Corresponding author.

${ }^{\ddagger}$ Interdisciplinary Center for Economic Science (ICES), Department of Economics, George Mason University. dhouser@gmu.edu 


\section{Introduction}

More than 1.5 million non-profits are registered in the US (NCCS, 2014). As a result, donors may find it challenging to select the charities whose programs have the greatest impact on the well-being of the participants. One solution is to directly acquire information before giving. However, this requires time and resources that donors may not have or may not be willing to invest (Yildirim and Krasteva 2014; Niehaus 2015). Another solution is to delegate this task to a specialized intermediary that vets different charitable projects and selects those with the highest promise or evidence of impact.

Intermediaries such as foundations, giving clubs, community funds and, more recently, donor-advised funds, are becoming central players in the giving market. ${ }^{1}$ Traditionally associated with high capacity donors, these intermediaries are working to expand their services to a broader base of donors. Despite this excitement, little is known about the role agency plays in charitable decisions. Delegating giving involves a loss of control over the final recipient of a donation, which may reduce the charitable impulse if donors experience less satisfaction - or warm glow (Andreoni 1989,1990) - from donations made by a third party. The decision to delegate thus involves a tradeoff: on the one hand, intermediaries reduce the relative cost of making informed, effective donations, which may attract donors who care about effective giving but have limited resources to acquire relevant information. On the other hand, donations made by better-informed agents may be unappealing to donors who derive non-monetary utility from retaining authority.

This paper is a first step toward understanding the economics of agency in the context of giving decisions. Using a "field in the lab" experiment, we vary across treatments whether donors can directly make real donations; delegate the choice of the recipient to an intermediary; or choose between direct and delegated donations. Donors can choose to costly acquire real information about charities' qualities before making direct donations, and we vary the characteristics of the intermediary institutions along two dimensions: the cost of information and the level of agency. Finally, all participants complete a survey to elicit the importance they place on impact giving and warm glow. Real intermediaries in fact differ in the amount of agency and effort they require from donors. Foundations and community funds typically accept only unrestricted gifts to the general cause they support. As such, donors have no control over final recipients, but bear no costs related to information acquisition. At the opposite end of the spectrum, giving clubs allow donors to make collective giving decisions. Thus, donors retain some control over their decisions, but also face some costs if they want to make informed donations (e.g., attending meetings, providing suggestions etc.).

Our data provide the first direct evidence of the distribution of (and relationship between) preferences for effective giving and agency, and show how these preferences affect

\footnotetext{
${ }^{1}$ Gifts from (non-corporate) foundations alone accounted for $15 \%$ of total US charitable contributions in 2014 (Source: Giving USA). Donor advised funds are experiencing double digit growth, with total assets held in 2014 of $\$ 70.7$ billion (Source: National Philanthropic Trust).
} 
the performances of different intermediaries. ${ }^{2}$ Consistent with previous studies (Fong and Oberholzer-Gee 2011), we find that only one-third of donors pay to make informed donations when intermediaries are not available, and we find no evidence of a strong aversion to delegation in the population. On the extensive margins however, different donors select into different intermediaries. Foundation-like intermediaries only attract donors who already place high value on effective giving, but fail overall to generate more informed giving. Conversely, club-like intermediaries attract donors who would not have otherwise made informed donations, but are unappealing to donors with high willingness to pay for information.

\section{Experimental design}

Our experiment consisted of five treatments. In all treatments, participants were endowed with $\mathrm{E} \$ 40$ (US $\$ 20$ ) (plus $\$ 5$ show up fee), and chose how to split their endowment between themselves and a real charity chosen from a large database of US charities. ${ }^{3}$ All participants completed a post-experiment survey about their attitudes toward giving.

In T1, our first baseline treatment, donors could only give by directly choosing a recipient. The user-friendly interface provided detailed information about all charities' missions and characteristics (e.g., type of cause, scope of activity, stated mission). ${ }^{4}$ The database also contained ratings and statistics about charities' financial health, accountability, and transparency. ${ }^{5}$ This information about charities' qualities was hidden at the beginning of the experiment, but donors could choose to pay $\mathrm{E} \$ 2$ to reveal these ratings and statistics for (up to) 20 charities of their choice. ${ }^{6}$ After subjects selected a charity, they chose how much to donate.

In T2, our second baseline treatment, donors could only give through an algorithm. Subjects faced the same user-friendly interface of $\mathrm{T} 1$, but could not directly select a recipient. To make a donation, they indicated: (i) a general cause they want to support (e.g., Health); (ii) a sub-cause (e.g., Medical research); and (iii) the scope of the activity (e.g., International, national, or regional charity ${ }^{7}$ ) ). The algorithm then selected the charity that, within these three criteria, scored highest in terms of financial health, accountability, and transparency. After seeing the charity chosen by the algorithm (and its qualities), donors chose how much to give. Giving through the algorithm had no cost. ${ }^{8}$

\footnotetext{
${ }^{2}$ For a field experiment on directed giving see Eckel et al. 2014.

${ }^{3}$ In all treatments, donors could choose not to donate at the beginning of the experiment, in which case the experiment ended immediately.

${ }^{4}$ See instructions in Appendix A for screenshots of the interface.

${ }^{5}$ These metrics come from Charity Navigator 2.0 (www.charitynavigator.org).

${ }^{6}$ The decision can be repeated. Each block of 20 charities costs $\mathrm{E} \$ 2$.

${ }^{7}$ If they chose regional, they could select the specific US state.

${ }^{8}$ Note that after the three criteria were chosen, donors could only give to the charity chosen by the algorithm. They could, however, donate zero, if they wanted to.
} 
In T3, our third and last baseline, donors could only give by "joining a club." Subjects faced the same user-friendly interface of $\mathrm{T} 1$, but could not directly select a recipient. If they wanted to make a donation, they were required to join the experimental session's club. Once in the club, donors could choose to pay to reveal the qualities of up to 20 charities at a reduced cost of $\mathrm{E} \$ 1$. Once every club member had chosen whether to reveal information, all charities whose qualities had been revealed by club members were shown to all members. Each member then chose whether to cast a vote for one charity in the pool at a cost of $\mathrm{E} \$ 1$. Votes determined which charity (or charities, up to 3 depending on votes) would receive donations from the club. After the vote, the winning charities were shown to all members, who then individually (and privately) chose how much to donate. ${ }^{9}$

Our treatment T4 allowed donors to choose between making a direct donation and giving through the algorithm. After this decision, the experiment proceeded as previously described. Finally, our treatment T5 allowed donors to choose between making a direct donation and giving through the club. As in T4, after this decision, the experiment proceeded as described. At the end of each treatment, participants completed a survey eliciting the importance they place on impact giving, information, and warm glow giving. ${ }^{10}$

We had a total of 285 subjects. The experiment was run at George Mason University, and was programmed using JavaScript.

\section{$3 \quad$ Hypotheses}

Our treatments varied the cost of making informed donations and the level of agency. Informed direct donations cost $\mathrm{E} \$ 2$ and provided maximum agency. Informed algorithm donations cost $\mathrm{E} \$ 0$ and provided minimum agency. Informed club donations could cost $\mathrm{E} \$ 0, \mathrm{E} \$ 1$, or $\mathrm{E} \$ 2$, depending on whether donors voted and/or paid for information, and provided intermediate agency. This variation allowed us to cast the following hypotheses.

H1: If there is a strong aversion to delegation in the population, fewer subjects will make positive donations in T2 and T3 compared to T1, and average donations will be lower.

In T2 and T3 donors can only make delegated donations, thus strong aversion to delegation predicts less frequent and smaller donations.

H2: The algorithm mechanism attracts donors who place a low value on agency and a positive value on informed giving.

Donors who place high value on agency will always prefer making direct donations (either informed or uninformed depending on their value for informed giving) over algorithm donations. When the value for agency is low instead, donors who value informed giving

\footnotetext{
${ }^{9}$ If more than one charity received votes, the charities with more votes (up to 3 ) received club donations, each receiving a donation corresponding to the share of votes received. Donors could donate zero, if they wanted to.

${ }^{10}$ See appendix A.
} 
at more than $\mathrm{E} \$ 2$ delegate to the algorithm, as the latter provides for free information they would have bought anyway. Donors who value informed giving at less than $\mathrm{E} \$ 2$ will delegate to the algorithm only if the benefit from an informed donation are greater than the (low) cost of delegating.

H3: The club mechanism attracts donors who value informed giving at less than E\$2, both with high and low value of agency.

Donors who value informed giving at more than $\mathrm{E} \$ 2$ will prefer direct (informed) over club donations, while those who value information at $\mathrm{E} \$ 2$ will be indifferent: this is because for these donors, the cost of acquiring information that is instrumental to an effective donation is the same for clubs $(\mathrm{E} \$ 1+\mathrm{E} \$ 1)$ and direct donations $(\mathrm{E} \$ 2)$. Donors who value information above $\mathrm{E} \$ 1$ but below $\mathrm{E} \$ 2$ and place high value on agency may delegate to the club, as $\mathrm{E} \$ 1$ allows them to cast a vote and therefore maintain (some) agency over decisions. Donors who place high value on agency but value information at less than $\mathrm{E} \$ 1$ will not delegate but make direct (uninformed) donations. Finally, donors who place low value on agency and value information at more than $\mathrm{E} \$ 0$ but less than $\mathrm{E} \$ 2$ will delegate to the club. 


\section{Results}

Table 1 details summary statistics for our treatments.

Table 1: Summary statistics by treatment

\begin{tabular}{|c|c|c|c|c|c|}
\hline Variables/Treatments & T1 & T2 & T3 & T4 & T5 \\
\hline$\overline{\text { Donated amount }}$ & $\begin{array}{c}5.167 \\
(7.87) \\
{[60]}\end{array}$ & $\begin{array}{c}6.913 \\
(9.15) \\
{[46]}\end{array}$ & $\begin{array}{c}5.517 \\
(8.94) \\
{[29]}\end{array}$ & $\begin{array}{c}6.500 \\
(9.93) \\
{[72]}\end{array}$ & $\begin{array}{c}5.423 \\
(8.32) \\
{[78]}\end{array}$ \\
\hline Positive Direct Donation (no pay) & $\begin{array}{c}6.929 \\
(9.50) \\
{[28]}\end{array}$ & & & $\begin{array}{c}10.59 \\
(10.85) \\
{[27]}\end{array}$ & $\begin{array}{c}4.556 \\
(4.78) \\
{[18]}\end{array}$ \\
\hline Positive Direct Donation (pay) & $\begin{array}{c}9.667 \\
(5.63) \\
{[12]}\end{array}$ & & & $\begin{array}{c}16.67 \\
(18.90) \\
{[3]}\end{array}$ & $\begin{array}{c}19.12 \\
(15.17) \\
{[8]}\end{array}$ \\
\hline Positive Algorithm Donation & & $\begin{array}{c}9.938 \\
(9.51) \\
{[32]}\end{array}$ & & $\begin{array}{c}10.15 \\
(9.43) \\
{[13]}\end{array}$ & \\
\hline Positive Club Donation (no pay) & & & $\begin{array}{c}5.181 \\
(4.46) \\
{[11]}\end{array}$ & & $\begin{array}{c}5.846 \\
(5.46) \\
{[13]}\end{array}$ \\
\hline Positive Club Donation (pay) & & & $\begin{array}{c}10.3 \\
(13.19) \\
{[10]}\end{array}$ & & $\begin{array}{c}8 \\
(6.95) \\
{[14]}\end{array}$ \\
\hline No donation $(\%)$ & $\begin{array}{l}0.333 \\
(0.48)\end{array}$ & $\begin{array}{l}0.304 \\
(0.47)\end{array}$ & $\begin{array}{l}0.276 \\
(0.45)\end{array}$ & $\begin{array}{l}0.403 \\
(0.49)\end{array}$ & $\begin{array}{l}0.321 \\
(0.47)\end{array}$ \\
\hline Delegated $(\%)$ & 0 & 1 & 1 & $\begin{array}{l}0.302 \\
(0.47)\end{array}$ & $\begin{array}{c}50.9 \\
(0.50)\end{array}$ \\
\hline Paid to get info (\%) & $\begin{array}{l}0.300 \\
(0.46)\end{array}$ & & $\begin{array}{l}0.476 \\
(0.51)\end{array}$ & $\begin{array}{c}0.0698 \\
(0.26)\end{array}$ & $\begin{array}{l}0.491 \\
(0.51)\end{array}$ \\
\hline Overall rating of charity chosen directly & $\begin{array}{l}3.475 \\
(0.64)\end{array}$ & & & $\begin{array}{c}3.2 \\
(0.96)\end{array}$ & $\begin{array}{l}3.308 \\
(1.01)\end{array}$ \\
\hline Overall rating of charity chosen by intermediary & & $\begin{array}{l}3.844 \\
(0.37)\end{array}$ & $\begin{array}{c}3.33 \\
(1.21)\end{array}$ & $\begin{array}{c}3.84 \\
(0.55)\end{array}$ & $\begin{array}{c}3.46 \\
(1.12)\end{array}$ \\
\hline Time spent searching & $\begin{array}{c}421.3 \\
(469.70)\end{array}$ & $\begin{array}{c}311.6 \\
(367.10)\end{array}$ & $\begin{array}{c}190.9 \\
(227.80)\end{array}$ & $\begin{array}{c}263.4 \\
(349.20)\end{array}$ & $\begin{array}{c}264.6 \\
(417.60) \\
\end{array}$ \\
\hline $\bar{N}$. & 60 & 46 & 29 & 72 & 78 \\
\hline
\end{tabular}

Note: Standard deviations in parenthesis, number of subjects in square brackets. 
R1: We do not find strong aversion to delegation: the extensive and intensive margins are the same across baselines.

In $\mathrm{T} 1$ donors could only donate by directly selecting a charity, and $33 \%$ chose not to donate. This percentage is not statistically different from the two baselines in which donors could only donate by delegating, T2 (30.4\%; $\mathrm{z}=-0.31 ; \mathrm{p}=0.75)$ and $\mathrm{T} 3(27.6 \%$; $0.54 ; \mathrm{p}=0.58) .{ }^{11}$ Thus, the probability of making a positive donation does not appear to depend on the level of control individuals have on the recipients of their donations (see Eckel et. $2014 \mathrm{Al}$ for similar results). Further, average positive donations were similar across baselines: the average in $\mathrm{T} 1$ was $\mathrm{E} \$ 7.75$; in $\mathrm{T} 2$ was $\mathrm{E} \$ 9.93$ ( $\mathrm{z}=1.74 ; \mathrm{p}=0.08)$; and in $\mathrm{T} 3$ was $\mathrm{E} \$ 7.61$ (T1 Vs. $\mathrm{T} 3 ; \mathrm{z}=-0.62 ; \mathrm{p}=0.53$ ). This result is remarkable, as most delegating donors are matched with charities with which they have little prior familiarity. These results are important, as they show that donors do not display a strong aversion to delegation per se. To explore further the relative importance of effective giving and control, we turn to treatments where delegation is optional (T4 and T5).

\section{R2: The algorithm attracts only donors who value information at more than E\$2.}

In our baseline treatment T1, 30\% of donors chose to acquire information about charities' quality at a cost of $\mathrm{E} \$ 2$. Informed donors donated on average $\mathrm{E} \$ 9.6$, while uninformed donors gave an average of $\mathrm{E} \$ 6.9(\mathrm{z}=2.22 ; \mathrm{p}=0.025)$. Thus, about one-third of $\mathrm{T} 1$ donors valued informed giving at more than $\mathrm{E} \$ 2$. This represents our baseline demand for information. Informed donors gave to better rated charities than those chosen by uninformed donors $(\mathrm{z}=-1.75 ; 0.079)$.

When participants had the option to delegate to the algorithm (T4), 30.2\% chose to do so, and the fraction of informed donors donating directly dropped to $6.9 \%$. Overall however, the number of informed donors in baseline $\mathrm{T} 1(30 \%)$ and $\mathrm{T} 4(37 \%)$ remained statistically indistinguishable $(\mathrm{z}=0.82 ; \mathrm{p}=0.40)$. These results suggest that the algorithm mechanism only attracts donors who place a high value on effective giving (e.g. above $\mathrm{E} \$ 2$ ), and that only a minority of such donors also place high value on agency (6.9\%). Thus, overall, the algorithm mechanism fails to attract donors who value information at less than $\mathrm{E} \$ 2$. A plausible explanation is that the algorithm involves a relatively high agency cost.

R3: The club doubles the percentage of informed donors by attracting donors who value information at less or equal than E\$2

When the delegating alternative is the club, we find two main results. First, the fraction of direct donors who paid to become informed remained unchanged compared to baseline $\mathrm{T} 1$ ( $30 \%$ in $\mathrm{T} 1$, and $30.7 \%$ in $\left.\mathrm{T} 5 ; \mathrm{z}=0.06 ; \mathrm{p}=0.94^{12}\right)$. Second, $50.9 \%$ of donors chose to make informed donations by giving through the club, raising the total percentage of informed donors from $30 \%$ in $\mathrm{T} 1$ to $66 \%$ in $\mathrm{T} 5(\mathrm{z}=3.42 ; \mathrm{p}=0.000)$. As hypothesized, the

\footnotetext{
${ }^{11}$ Nor from treatments in which donors have the option to delegate, $\mathrm{T} 4(40.3 \% ; \mathrm{z}=0.81 ; \mathrm{p}=0.41)$ and $\mathrm{T} 5$ $(32.1 \% ; \mathrm{z}=-0.15 ; \mathrm{p}=0.87)$.

${ }^{12}$ Informed direct donors in $\mathrm{T} 5$ represent the $15.1 \%$ of the entire pool of donors (including club donors).
} 
club was unappealing to donors valuing information at more than $\mathrm{E} \$ 2$, while attracting donors with lower valuation of information. Looking at voting and information purchase decisions, we find that $15 \%$ of club donors did not pay for information or pay to vote; $8 \%$ paid for information but did not vote; $33 \%$ did not purchase information but voted; and $44 \%$ both paid for information and voted. Thus, overall, $56 \%$ of club donors valued information at less than $\mathrm{E} \$ 1$, while $44 \%$ of donors were willing to pay $\mathrm{E} \$ 2$ to participate in the club despite the fact that they likely would not have purchased information at $\mathrm{E} \$ 2$ for a direct donation. Figure 1 summarizes donors' selection into different giving mechanisms. Our next results provide a possible explanation for why clubs induce high overall participation and willingness to pay for informed giving.

Figure 1: Percentage of donors making (un)informed donations via direct donation or delegation in $\mathrm{T} 1$ (direct donation only), T4 (direct donation Vs. algorithm), and T5 (direct donation Vs. club)

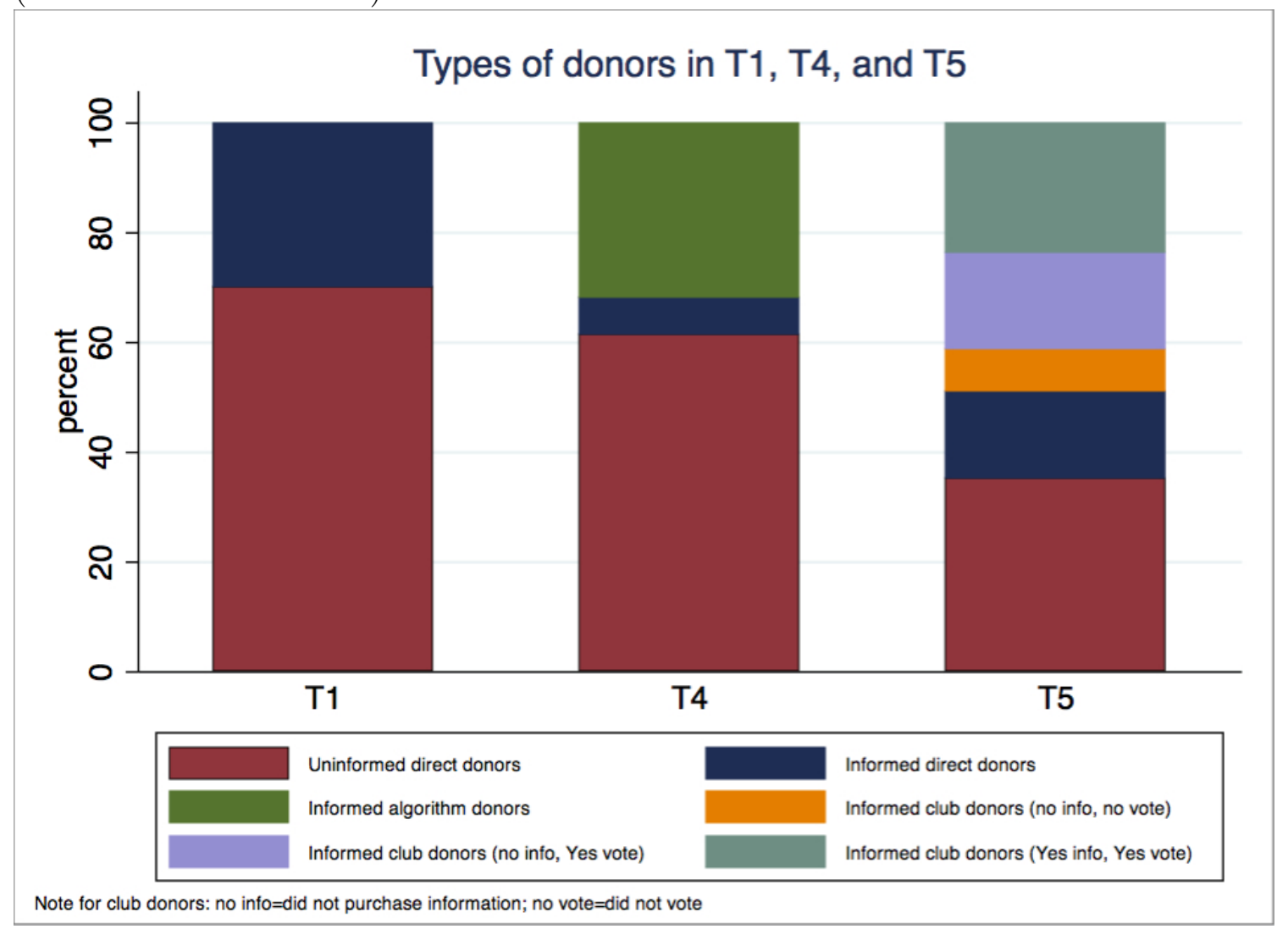


R4: In our one-shot setting, the presence of intermediaries does not increase average giving, but increases the allocation efficiency of gifts

Average positive giving in our baseline treatment $\mathrm{T} 1$ was $\mathrm{E} \$ 7.75$, which is not statistically significantly different from average donations made in T4 (both direct and algorithm donations, $\mathrm{E} \$ 10.62 ; \mathrm{z}=-1.1 ; \mathrm{p}=0.268$ ) and in $\mathrm{T} 5$ (both direct and club donations, $\mathrm{E} \$ 7.98$; $\mathrm{z}=0.19, \mathrm{p}=0.844$ ). While giving was similar, the quality of charities was not. Donors who gave through the algorithm donated to charities with higher accountability, transparency, and financial health ratings, both compared to T4 direct donors $(\mathrm{z}=2.7 ; \mathrm{p}=0.006)$ and $\mathrm{T} 1$ direct donors $(\mathrm{z}=2.3 ; \mathrm{p}=0.02)$. Further, the presence of the algorithm mechanism reduced the per capita cost of becoming informed by $76 \%$ compared to the baseline T1 $(\mathrm{z}=-2.75 ; \mathrm{p}=0.005)$. Also, clubs had positive effects on the quality of charities: the average quality of club donations was not statistically different from direct donations. However, clubs selected only a few charities, making the average quality very sensitive to outliers. If we exclude charities that scored 0 or 1 on quality ( 2 out of the total 19 club charities; 4 out total 96 directly selected charities, both informed and uninformed), then clubs indeed gave to better charities than individuals $(\mathrm{z}=-2.01 ; \mathrm{p}=0.045)$.

R5: Club donors and uninformed direct donors value warm glow significantly more than algorithm donors and informed direct donors

In a post-experiment survey, participants were asked whether they generally respond more to solicitations that appeal to their heart or that highlight the impact and efficacy of the charity (see Appendix A). This can be considered as a proxy for the importance of warm glow giving (see Karlan and Wood 2014; List, Murphy and Price 2015). Unsurprisingly, we find that uninformed donors reported placing a higher value on warm glow than their informed counterparts $(\mathrm{z}=1.79 ; \mathrm{p}=0.072)$. However, only direct informed donors and algorithm donors drove this difference: while algorithm donors and direct informed donors displayed lower preferences for warm glow than uninformed donors $(\mathrm{z}=2.21 ; \mathrm{p}=0.027)$, club donors displayed warm glow preferences similar to their uninformed counterparts. A probit model (not reported here, standard errors clustered at the session level) shows similar results: conditional on giving, a $20 \%$ increase in reported preferences for warm glow corresponds to a $50.9 \%$ decrease in the probability of delegating to the algorithm $(\mathrm{p}=0.021)$, but has no effect on the probability of delegating to the club $(\mathrm{p}=0.313)$. Finally, a two-sided jonkeree-Terprsa test reveals that as self-reported warm glow preferences increase, average donations decrease $\left(J^{*}=-2.44 ; \mathrm{p}=0.014\right)$. These results suggest that the popularity of the club mechanism might be linked to the club's ability to preserve warm glow, either due to the possibility of giving to multiple charities (see Karlan and Wood 2015), or to the collective nature of decisions. 


\section{Conclusions}

The charitable intermediary sector is growing rapidly. A vibrant intermediary sector, while certainly not immune from challenges ${ }^{13}$, may benefit the giving market. Potential benefits include more effective and coordinated allocation of gifts; more regular giving; more competition in a sector currently dominated by a few large intermediaries (Andreoni and Payne 2013); and, as a result, stronger support to social causes for which these intermediaries provide little or no support.

We provide preliminary but important evidence on the interplay between donors' preferences for effective giving and agency, as well as suggestive evidence on the role of warm glow in delegation decisions. Although only a minority of donors (one-third) is willing to pay to make informed donations, we do not find a strong aversion to delegating giving to better-informed parties, when this is the only option. This might explain why fundraising campaigns that solicit donations to pre-vetted charities, such as those run by large firms, are relatively successful. On the extensive margins however, we find that different intermediaries attract different donors. Foundation-like intermediaries attract donors who place high value on effective giving, but are less attractive to donors less concerned by effective giving and more concerned by warm glow. Club-like intermediaries have the opposite effect: donors with high preferences for effective giving do not join our experimental clubs, but donors who would not make the effort to become informed on their own do. As such, the presence of clubs more than doubles the fraction of donors who make informed donations.

Using stylized versions of real intermediaries, we provide lower bound estimates of the demand for intermediaries and their effect on giving in a one shot setting. An important avenue for future research is to explore, in more natural settings, the role of intermediaries in inducing more regular giving.

\footnotetext{
${ }^{13}$ See Claß et al. 2015 and Coffman 2015.
} 


\section{References}

[1] James Andreoni. Giving with impure altruism: applications to charity and ricardian equivalence. The Journal of Political Economy, pages 1447-1458, 1989.

[2] James Andreoni. Impure altruism and donations to public goods: A theory of warmglow giving. The economic journal, 100(401):464-477, 1990.

[3] James Andreoni and A Abigail Payne. Charitable giving. Handbook of public economics, 5:1-50, 2013.

[4] Giving USA annual report. http://www.givinginstitute.org/?page= GUSAAnnualReport, 2014.

[5] Nadine Chlaß, Lata Gangadharan, Kristy Jones, et al. Charitable giving and intermediation. Jena Economic Research Papers, 2015:021, 2015.

[6] Lucas Coffman. Intermediaries in fundraising inhibit quality-driven charitable donation. Unpublished manuscript, 2015.

[7] Catherine C Eckel, David Herberich, and Jonathan Meer. A field experiment on directed giving at a public university. NBER Working Paper, (w20180), 2014.

[8] Christina M Fong and Felix Oberholzer-Gee. Truth in giving: Experimental evidence on the welfare effects of informed giving to the poor. Journal of Public Economics, 95(5):436-444, 2011.

[9] National Center for Charitable Statistics. http://nccs.urban.org/statistics/ quickfacts.cfm.

[10] Dean Karlan and Daniel H Wood. The effect of effectiveness: Donor response to aid effectiveness in a direct mail fundraising experiment. NBER Working Paper Series, page 20047, 2014.

[11] Silvana Krasteva and Huseyin Yildirim. Reprint of:(un) informed charitable giving. Journal of Public Economics, 114:108-120, 2014.

[12] Paul Niehaus. A theory of good intentions. Working Paper, 2014.

[13] National Philanthropic Trust. Annual report on donor advised funds. http://www . nptrust.org/daf-report/index.html, 2014. 


\section{Appendix A (not for publication)}

\section{INSTRUCTIONS: Direct donation Vs. Delegation to Algorithm}

Your ID number:

Thank you for participating in today's experiment. You've earned a \$5 show-up bonus for participating. In reading and following the instructions below, you have the potential to earn more. In the experiment you will receive Experimental Dollars (E\$s), which will be converted into cash (US Dollars) at the end of the experiment.

The conversion rate from Experimental Dollars (E\$) to cash (US Dollars) is the following: 2 Experimental Dollars (E\$s) are worth 1 US Dollar in cash.

In today's experiment you will be assigned a randomly generated ID number: this ID number will identify your choices in today's experiment. Your ID number is written at the top of this page.

Please note that other participants will not be told your name, and you will not be told their names.

The next section gives a summary description about today's experiment and your task.

\section{YOUR TASK:}

You have earned $\mathrm{E} \$ 40$ for participating in today's experiment (excluding show up fee).

In today's experiment you will be given the possibility to donate any amount from $\mathrm{E} \$ 0$ to $\mathrm{E} \$ 40$ of your $\mathrm{E} \$ 40$ to one charitable organization. That charity will receive the amount you chose to donate, and you will keep the rest.

The pool of available charities includes about 5000 non-profit organizations rated by Charity Navigator.

Charity Navigator is an independent American non-profit organization that evaluates charities in the United States. Charity Navigator provides free ratings of the Financial Health and Accountability \& Transparency of charities, and its stated goal is "to advance a more efficient and responsive philanthropic marketplace in which givers and the charities they support work in tandem to overcome our nation's and the world's most persistent challenges".

A brief description of how Charity Navigator rates charities according to charities' financial health, accountability, and transparency has been handed to you (the other handout called "CHARITY NAVIGATOR'S RATING METHODOLOGY"). You may use it as a reference during the experiment.

${ }^{1}$ Instructions for Baseline T1 (direct donation only) and Baseline T2 (Algorithm delegation only) use same wording and include only the relevant sections. 


\section{HOW TO MAKE YOUR DECISION?}

If you choose to donate a positive amount, your task is to choose a recipient for your donation.

If you do not wish to donate in today's experiment, a "Don't Donate" button will be available and you will not be asked to make such decision.

The list will be shown on a user-friendly computer interface. For each charity, the database reports the following information:

1) What is the sector of activity of the charity (e.g. Health).

2) What is the sub-sector of activity or specific mission of the charity (e.g. for the Health sector, one example is "Patient and Family Support"). The full list of sectors and subsectors is available in the handout "CHARITY NAVIGATOR'S RATING METHODOLOGY".

3) What is the scope of work of the charity (e.g. whether the charity operates nationally, internationally, or in a specific US state).

4) A set of Charity Navigator's ratings and indices of each charity's financial health, accountability and transparency. As explained further, these ratings are not visible at the beginning of the experiment, but you can choose to reveal the ratings and indices of charities of your choice at a fixed cost of $\mathrm{E} \$ 2$.

You have 2 alternative ways of making a donation:

\section{1) Donate by directly selecting a charity.}

2) Donate using algorithm.

As explained further, if you choose to directly select a charity, you will have to select one charity directly from the database. If you choose to donate using the algorithm, you will provide details of the type of cause you want to support, and an algorithm will find for you the charity that, within your criteria, scores highest according to Charity Navigator's ratings of financial health, accountability, and transparency.

Before you decide whether you want to directly select a charity, donate using algorithm, or not donate in today's experiment, you will be given time to familiarize with the database. The time you spend on the database is up to you.

We first describe how you can explore the database, if you wish to do that, and then explain how to you can make your decision between direct donation and donation using algorithm (or no donation).

\section{HOW TO EXPLORE THE DATABASE?}

If you wish to explore the database, or lookup for specific charities you have the following methods. 
1) You can use the search box at the top of the interface to search for your charities by name. Similarly to a web search engine, when you type the database "shrinks" to only the charities that contain in their name what you typed. If you delete what you typed, you go back to the full database.

2) You can scroll the database using the scroll bar, and use the tabs at the bottom of the database.

3) You can sort the database by sector of activity of charities, subsector, scope of activity and location. To sort by these variables simply click on the variable's name. You can find the full list of sectors and subsectors in the other handout called "CHARITY NAVIGATOR'S RATING METHODOLOGY”.

\section{HOW TO KNOW THE MEANING OF EACH VARIABLE AND WHAT EACH CHARITY DOES?}

In the computer interface, you can always read the description and definition of every variable (including Charity Navigator's ratings or indices) by simply placing the mouse pointer on the variable's name (the first row of the database): a description and explanation of that variable will appear. Similarly, if you place the mouse pointer on the name of the charity, a description of its stated mission will appear (the first column of the database).

\section{HOW TO REVEAL CHARITIES' RATINGS?}

You can choose to reveal the Charity Navigator's ratings and indices of charities of your choice. The database contains Charity Navigator's Overall Ratings, Financial Health-specific ratings, Accountability \& Transparency-Specific ratings, and more detailed indices. The ratings are based on a 0 to 4 stars scale $(0$ is the lowest rating, 4 is the highest), and capture the relative ranking of charities based on their financial health, accountability and transparency performances. In addition to these 3 general ratings, the database contains more specific indices of each charity's activities.

You can pay a fixed cost of $\mathrm{E} \$ 2$ to reveal all the ratings and indices of (up to) 20 charities of your choice. On the right hand side of the interface you will find a button called "reveal charities' ratings". By clicking the button (and then confirm your decision), you will be able to reveal ratings of (up to) 20 charities. To reveal all the ratings and indices of a specific charity you can simply click on the name of that charity: a popup window will appear asking you to confirm your decision, and the ratings of that charity will be revealed to you. If you reveal ratings and indices for all 20 charities, but you want to reveal more charities, you can click again on the button "reveal charities' ratings": this will give you (up to) 20 more charities to reveal, at the same fixed cost of $\mathrm{E} \$ 2$.

As you reveal charities' ratings through the database, you may want to have all the charities revealed in one place. To do so, you can click the button "Collect Revealed Charities". This will place all the revealed charities together at the top of the database.

We now describe the two methods you have to make a donation today.

\section{1) Direct donation}


If you choose to donate directly, your decision consists in selecting a charity present in the database. To do so, simply click the line corresponding to that charity (it will become highlighted in blue). You can then click the button "Donate to Selected Charity". Note that until you click the button "Donate to Selected Charity" you decision is not finalized, meaning that you can select another charity by clicking on it. Once you have selected and confirmed a charity, you will move to a new screen and select how much you want to donate.

We now describe the second method you can use to make a donation today.

\section{2) Donate using Algorithm}

If you choose to donate using the algorithm, you decision consists in selecting a cause you care about and its scope of activity. As explained further, you will not be able to select the specific recipient of your donation: instead, an algorithm will find for you the charity that, within the criteria you have indicated, has the highest Charity Navigator ratings in terms of Financial Health, Accountability and Transparency.

More precisely you will be able to select each of the following criteria for your charity:

1) General Cause: this is the general cause you are interested in supporting.

2) Sub-sector cause: each of the previous general causes has several subsectors of activities. Once you have chosen your general cause, you can refine your criteria and indicate one subsector.

3) Scope of Work: You will be able to indicate whether you want your donation to go to a charity that operates nationally, internationally, or in a specific US state.

The full list of list of sectors and subsectors you can choose from are on the first page of the handout "CHARITY NAVIGATOR'S RATING METHODOLOGY". Take a moment now to look at it.

To make a donation using the algorithm, you can click on the button "Donate using algorithm".

Once you confirm your decision, you will move to a decision screen in which you will be able to specify the details of what cause you want to support. The algorithm will then find for you the charity that, within your criteria, scores highest in terms of Charity Navigator's ratings of Financial Health, Accountability \& Transparency. You will then choose how much you want to donate to the charity.

Important note: The interface is user friendly: for every decision that involves a cost for you or a final decision (e.g. do not donate, reveal ratings, donate directly, donate using algorithm etc.), a pop-up window will appear asking you to confirm your decision. If you clicked a button by mistake you can always undo your decision. Also note that you can drag all columns (as in Excel), to reveal text in the cells. 
You will be paid one by one in cash and in private at the end of the experiment.

The ID number you have been randomly assigned today will be used as the name of the donor to make the donation you have selected. When all donations are made, all participants for today's session will receive an email (in BCC) announcing that the receipts of the donations are available. If you want to receive your receipt, simply email us your ID number for today's experiment and/or the charity you have chosen, and we will email you the receipt.

Note that no personal information will be shared in this email, nor your personal information, such as your email address, will be shared with the charity you have selected. Please raise your hand if you have any question.

Please take a moment now to mark on the first page of these instructions the number of participants, as you will need this information in the survey following the experiment.

The next pages in this set of instructions contain snapshots of the interface you will use today. We will now give you few moments to look at these pictures and their description: this will help you better to understand how the program interface works. After that, we will distribute a short comprehension quiz, and you will then be able to start the experiment. 


\section{Screenshots}

Figure 1: Main program interface (notice the 5 buttons: "Donate to selected charity"; "Donate using algorithm"; "Don't donate"; "Reveal charities' ratings"; Collect revealed charities")

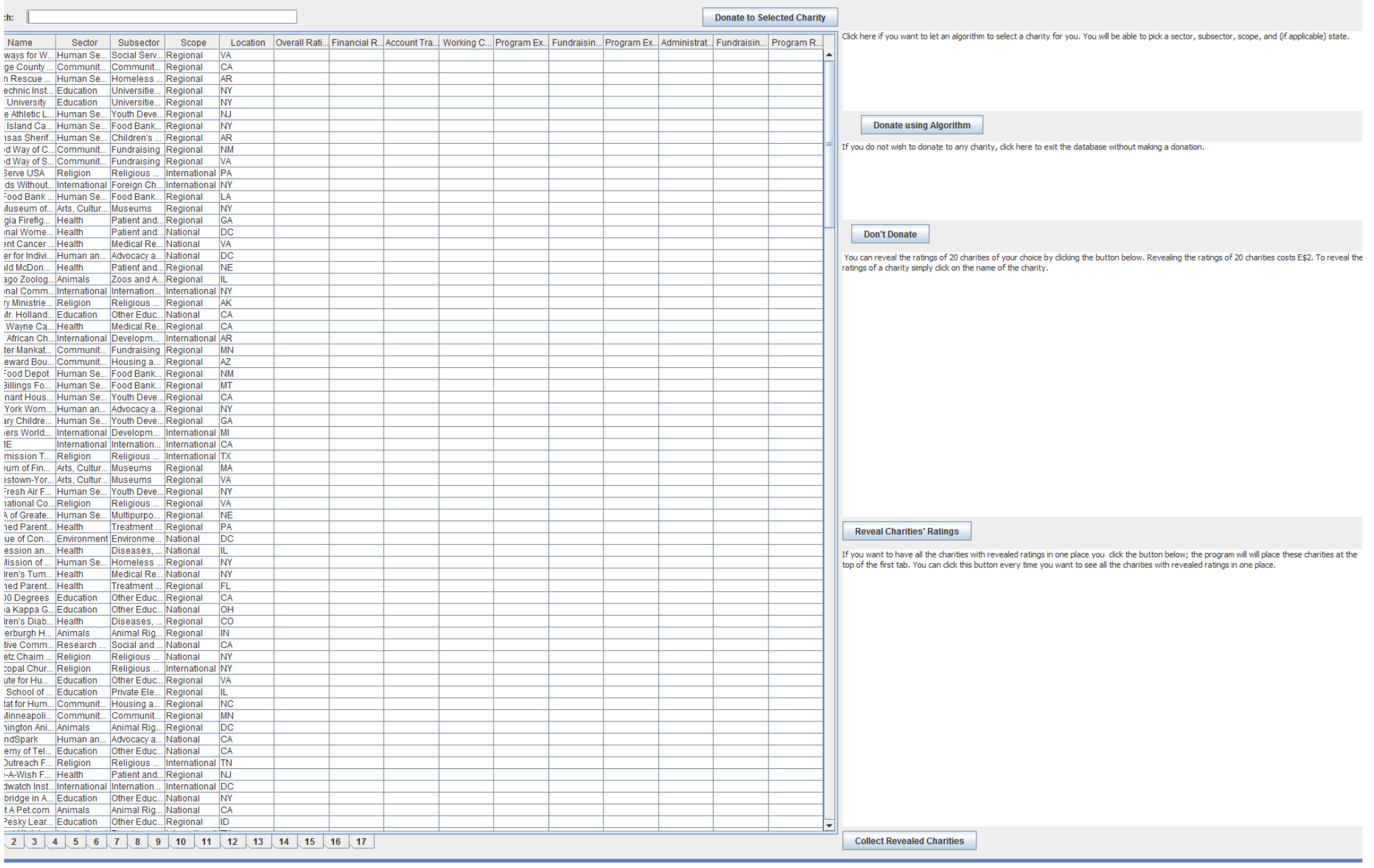



gure 2: Place the mouse on the charity's name and a description of the charity's mission
will appear

\begin{tabular}{|c|c|c|c|c|c|c|c|c|c|c|c|c|c|}
\hline \multicolumn{14}{|l|}{ arch: } \\
\hline Name & Sector & Subsector & Scope & & ocation & Overall Rati.. & Financial $\mathrm{R}$. & Account Tra... & Working $\mathrm{C}$. & Program Ex.. & Fundraisin... & Program Ex. & Administr: \\
\hline nazon Conse. & Environment & Environme. & Internationa & $D C$ & & & & & & & & & \\
\hline onprofit Lead... & Education & Other Educ. & National & MO & & & & & & & & & \\
\hline oston Ballet & Arts, Cultur... & Performing. & Regional & MA & & & & & & & & & \\
\hline izona-Sonora ... & Arts, Cultur... & Museums & Regional & $A Z$ & & & & & & & & & \\
\hline pina Bifida As... & Health & Diseases, & National & VA & & & & & & & & & \\
\hline orldServe Min... & Religion & Religious .. & Internationa & $T X$ & & & & & & & & & \\
\hline ational Jewis... & Religion & Religious.. & Internationa & NY & & & & & & & & & \\
\hline ie New World ... & Communit.. & Fundraising & Internationa & NY & & & & & & & & & \\
\hline dependent $\mathrm{M} . .$. & Arts, Cultur... & Public Bro.. & National & CA & & & & & & & & & \\
\hline evens-Swan ... & Animals & Animal Rig. & Regional & NY & & & & & & & & & \\
\hline \multicolumn{14}{|c|}{$\begin{array}{l}\text { larity: WFunded in 1910, the Stevens-Swan Humane Society (SSHS) of Oneida County provides a } \\
\text { lobalGG } \\
\text { safe haven to all domestic pets that must be surrendered, are stray, abandoned, }\end{array}$} \\
\hline $\begin{array}{l}\text { adrus safe hav } \\
\text { anned }\end{array}$ & $\begin{array}{l}\text { ven to all dome } \\
\text { ss, abused, or }\end{array}$ & $\begin{array}{l}\text { estic pets the } \\
\text { r injured. The }\end{array}$ & $\begin{array}{l}\text { th must be su } \\
\text { sSHS serve. }\end{array}$ & rende & $\begin{array}{l}\text { red, are } \\
\text { safe ha }\end{array}$ & $\begin{array}{l}\text { stray, abandor } \\
\text { ten for nearly } 5\end{array}$ & $\begin{array}{l}\text { ned, } \\
5,000 \text { animals }\end{array}$ & & & & & & \\
\hline $\begin{array}{l}\text { ational each yea } \\
\text { ternatie }\end{array}$ & ar that need to & be sheltere & d, regardless & of circ & umstan & e. Taking care & of these & & & & & & \\
\hline VCA of the healt & th and safety $c$ & & imals and lo & :al cor & mmunit & s of Oneida C & & & & & & & \\
\hline ity Year York. We & e make sure th & hat the anim & & & ble as $p$ & ssible, and th & hat they receive & & & & & & \\
\hline & $\begin{array}{l}\text { dical attention t } \\
\text { related proble }\end{array}$ & they need. W & $e$ also serve & is a sc & ource fo & information fo & & & & & & & \\
\hline & & & & & & & & & & & & & \\
\hline S. Dream Aca... & Human $\mathrm{Se} . .$. & Children's. & Regional & MD & & & & & & & & & \\
\hline ipps Conser... & Environment & Botanical... & Regional & PA & & & & & & & & & \\
\hline liance for Just... & Human an... & Advocacy a. & National & DC & & & & & & & & & \\
\hline evada Museu... & Arts, Cultur... & Museums & Regional & NV & & & & & & & & & \\
\hline jian Access & Religion & Religious .. & Internationa & CA & & & & & & & & & \\
\hline & Arts, Cultur... & Public Bro.. & Regional & MO & & & & & & & & & \\
\hline ymouth Housi... & Communit... & Housing a.. & Regional & WA & & & & & & & & & \\
\hline orld Neighbors & International & Developm.. & Internationa & OK & & & & & & & & & \\
\hline id-Ohio Foodb... & Human Se... & Food Bank. & Regional & $\mathrm{OH}$ & & & & & & & & & \\
\hline ayton Society .. & Arts, Cultur... & Museums & Regional & $\mathrm{OH}$ & & & & & & & & & \\
\hline nice Family. & Health & Treatment. & Regional & CA & & & & & & & & & \\
\hline nerica-Israel ... & International & Foreign $\mathrm{Ch}$. & Internationa & NY & & & & & & & & & \\
\hline islin Diabetes... & Health & Diseases. & National & MA & & & & & & & & & \\
\hline ancer Survivor... & Health & Diseases, & National & TX & & & & & & & & & \\
\hline jod For The P... & International & Humanitari. & Internationa & $\mathrm{FL}$ & & & & & & & & & \\
\hline jundation for ... & Health & Patient and & Regional & WI & & & & & & & & & \\
\hline incinnati Natu... & Environment & Botanical ... & Regional & $\mathrm{OH}$ & & & & & & & & & \\
\hline an Antonio Fo... & Human $\mathrm{Se} . .$. & Food Bank. & Regional & TX & & & & & & & & & \\
\hline nited Way of N... & Communit... & Fundraising & Regional & NY & & & & & & & & & \\
\hline mon Youth Fo... & Education & Other Educ. & National & IN & & & & & & & & & \\
\hline aine Public Br... & Arts, Cultur... & Public Bro.. & Regional & ME & & & & & & & & & \\
\hline ew Jersey Sy... & Arts, Cultur... & Performing. & Regional & NJ & & & & & & & & & \\
\hline ie Heritage F... & Research. & Social and. & National & DC & & & & & & & & & \\
\hline olumbus Aca... & Education & Private Ele. & Regional & $\mathrm{OH}$ & & & & & & & & & \\
\hline ariety the Chil... & Communit... & Fundraising & Regional & $P A$ & & & & & & & & & \\
\hline illdlife Conser... & Animals & Wildlife $\mathrm{Co}$. & Internationa & CA & & & & & & & & & \\
\hline ospice Educat... & Human Se. & Social Serv. & National & ME & & & & & & & & & \\
\hline mball Union ... & Education & Private Ele. & Regional & $\mathrm{NH}$ & & & & & & & & & \\
\hline jod for Others & Human Se... & Food Bank. & Regional & VA & & & & & & & & & \\
\hline Jod Bank of th... & Human $\mathrm{Se} . .$. & Food Bank. & Regional & Co & & & & & & & & & \\
\hline ederik Meijer ... & Environment & Botanical ... & Regional & MI & & & & & & & & & \\
\hline ational Tropic... & Environment & Botanical... & Regional & $\mathrm{HI}$ & & & & & & & & & \\
\hline vat Haviva Ed... & International & Internation. & Internationa & NY & & & & & & & & & \\
\hline onterey Bay A... & Animals & Zoos and $A$ & Regional & CA & & & & & & & & & \\
\hline liance for Sch... & Education & Other Educ. & National & $D C$ & & & & & & & & & \\
\hline ena/Francis . & Human $\mathrm{Se}$ & Homeless. & Regional & NE & & & & & & & & & \\
\hline ayton History & Arts, Cultur... & Libraries,... & Regional & $\mathrm{OH}$ & & & & & & & & & \\
\hline imal Welfare ... & Animals & Animal Rig. & Regional & VA & & & & & & & & & \\
\hline umane Societ... & Animals & Animal Rig. & Regional & NY & & & & & & & & & \\
\hline ational Comm... & Religion & Religious .. & National & NY & & & & & & & & & \\
\hline assanetta Spr... & Religion & Religious .. & Regional & VA & & & & & & & & & \\
\hline iracle Flights $f .$. & Health & Patient and. & National & NV & & & & & & & & & \\
\hline ew York Com... & Communit... & Communit. & Regional & NY & & & & & & & & & \\
\hline eedom Institute & e Health & Treatment. & Regional & NY & & & & & & & & & \\
\hline alifornia Polic... & Human Se... & Youth Deve & Regional & $C A$ & & & & & & & & & \\
\hline enrickton Cent... & Human $\mathrm{Se} \ldots$ & Social Serv. & Regional & MI & & & & & & & & & \\
\hline \begin{tabular}{l|l|l}
2 & 3 & 4
\end{tabular} & \begin{tabular}{|l|l|l|}
4 & 5 & 6 \\
\end{tabular} & \begin{tabular}{|l|l|l}
7 & 8 & 5
\end{tabular} & \begin{tabular}{|l|l|}
10 & 11 \\
\end{tabular} & 12 & 13 & \begin{tabular}{|l|l|}
14 & 15 \\
\end{tabular} & \begin{tabular}{|l|l|}
16 & 17 \\
\end{tabular} & & & & & & \\
\hline
\end{tabular}

gure 3: Place the mouse on the name of any variable and a description and explanation will appear 
Irch:

Name Sector Subsector Scope orways for W... Human Se... Social Serv... Regional ange County ... Communit... Communit... Regional on Rescue ... Human Se... Homeless ... Regional Iytechnic Inst... Education Universitie... Regional ce University Education Universitie... Regional lice Athletic L... Human Se... Youth Deve... Regional g Island Ca... Human Se... Food Bank... Regional ansas Sherif... Human Se... Children's ... Regional ited Way of C... Communit... Fundraising Regional ited Way of S... Communit... Fundraising Regional \begin{tabular}{l|l|l|l|l}
\hline rServe USA & Religion & Religious ... International PA \\
\hline
\end{tabular} ends Without... International Foreign $\mathrm{Ch}$... International NY Food Bank ... Human Se... Food Bank... Regional LA Museum of.. Arts, Cultur.. Museums Regional orgia Firefig. Health mantional ilonal Wome... Health Patient and... National vent Cancer... Mealth Medical Re... National nter for Indivi... Human an... Advocacy a... National \begin{tabular}{l|l|l}
\hline nald McDon... & Health & Patient and... Regional \\
\hline
\end{tabular} icago Zoolog... Animals Zoos and A... Regional IL tional Comm... International Internation... International NY tory Ministrie... Religion $\quad$ Religious ... Regional Mr. Holland... Education Other Educ... National in Wayne Ca. Health Medical Re Regional CF African Ch... International Developm... International AR eater Mankat... Communit... Fundraising Regional MN meward Bou... Communit... Housing a... Regional e Food Depot Human Se... Food Bank... Regional Billings Fo... Human Se Food Bank. Regiona venant Hous... Human Se... Youth Deve... Regional w YorkWom... Human an... Advocacy a... Regional Ivary Childre... Human Se... Youth Deve... Regional tners World... International Developm.... International MI \begin{tabular}{l|l|l}
\hline AME & International Internation... & International CA
\end{tabular} \begin{tabular}{l|l|l|l}
\hline mmission T... & Religion & Religious ... International TX
\end{tabular} \begin{tabular}{l|l|l}
\hline seum of Fin... & Arts, Cultur... Museums & Regional
\end{tabular} nestown-Yor... Arts, Cultur... Museums Regiona eFresh Air F... Human Se... Youth Deve... Regional \begin{tabular}{l} 
2rnational Co... Religion \\
\hline
\end{tabular} \begin{tabular}{lll|l}
\hline CA of Greate... & Human $\mathrm{Se} .$. & Multipurpo... & Regional
\end{tabular} \begin{tabular}{ll|l|l} 
CA of Greate... & Human Se... & Multipurp .... & Regional \\
\hline inned Parent... & Health & Treatment ... & Regional
\end{tabular} \begin{tabular}{l|l|l|l} 
inned Parent... & Health & Treatment ... & Regional \\
\hline ague of Con... & Environment Environme... & National
\end{tabular} pression an... Health Diseases, ... National yission of ... Human Se... Homeless ... Regional ildren's Tum... Health Medical Re... National inned Parent.. Health Treatment... Regional 000 Degrees Education Other Educ.. Regional ppa Kappa G... Education Other Educ... National \begin{tabular}{l|l|l}
\hline ildren's Diab.... Health & Diseases, ... & Regional \\
\hline
\end{tabular} iderburgh $\mathrm{H}$... Animals Animal Rig... Regional ative Comm... Research ... Social and ... National ofetz Chaim ... Religion Religious ... National \begin{tabular}{l|l|l|l|l|l}
\hline ofetz Chaim ... & Religion & Religious ... & National & NY \\
\hline scopal Chur... & Religion & Religious ... & International NY
\end{tabular} School of .. Education Private Ele... Regional bitat for Hum... Communit... Housing a... Regional \begin{tabular}{l|l|l|l|}
\hline e Minneapoli... & Communit... & Communit... & Regional \\
\hline \hline
\end{tabular} \begin{tabular}{l|l|l|l}
\hline ishington Ani... Animals & Animal Rig... & Regional \\
\hline
\end{tabular} sundSpark $\quad$ Human an... Advocacy a... National Idemy of Tel... Education Other Educ... National Outreach F... Religion Religious ... International TN \begin{tabular}{l|l|l}
\hline ke-A-Wish F... & Health & Patient and... Regional \\
\hline
\end{tabular} \begin{tabular}{c|l|l|l}
\hline rldwatch Inst... International Internation... International $D C$ &
\end{tabular} \begin{tabular}{l|l|l|l}
\hline mbridge in A... & Education & Other Educ... National & NY
\end{tabular} \begin{tabular}{l|l|l|l|l} 
mbridge in A... & Education & Other Educ... & National & NY \\
\hline opt A Pet.com & Animals & Animal Rig... & National & CA \\
\hline e Pesky Lear... & Education & Other Educ... & Regional & ID
\end{tabular} Location Overall Rati... Financial R... Account Tra... Working C... Program Ex... Fundraisin... Program Ex... Adminis \begin{tabular}{l|l}
\hline VA & This is the overall rating of a charity. \\
\hline
\end{tabular} The scale is constructed from the different metrics of financial health and efficiency, and accountability \begin{tabular}{l|l} 
and transparency, and goest \\
1(lowest) to 4 (highest).
\end{tabular} P MA PA A A DA C

Y

Y

A

A

M

M
MT Y A A \begin{tabular}{l} 
VA \\
\hline NY \\
\hline VA \\
\hline
\end{tabular} NE PA \begin{tabular}{|l|l}
\hline IL \\
\hline NY \\
\hline NY
\end{tabular} NY FL $\mathrm{H}$ O A NY A NC MN A DJ \begin{tabular}{|l|l|l|l|l|l|l|l|l|l|l|l|l|l|l|l|l|}
\hline 2 & 3 & 4 & 5 & 6 & 7 & 8 & 9 & 10 & 11 & 12 & 13 & 14 & 15 & 16 & 17 \\
\hline
\end{tabular}

\section{gure 4: If you choose to pay $\mathrm{E} \$ 2$ and reveal 20 charities: To reveal the ratings of a charity, click on the name of the charity (a pop up window will appear asking you to}




\section{confirm and reminding you how many "reveals" you have left). Below is an example}

arch:

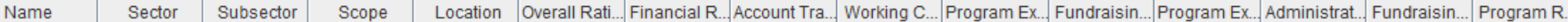
iazon Conse... Environment Environme... International DC \begin{tabular}{l|l|l|l} 
inprofit Lead... & Education & Other Educ... National & MO
\end{tabular} \begin{tabular}{l|l|l|l}
\hline ston Ballet & Arts, Cultur... & Performing... & Regional \\
\hline
\end{tabular} zona-Sonora ... Arts, Cultur... Museums Regional $A Z$ ina Bifida As... Health Diseases, National rrldServe Min... Religion Religious ... International TX \begin{tabular}{c|c|c|c|}
\hline tional Jewis... & Religion & Religious ... & International NY \\
\hline
\end{tabular} e New World ... Communit... Fundraising International NY \begin{tabular}{l|l|l|l} 
Jependent M... Arts, Cultur... & Public Bro... & National & CA \\
\hline
\end{tabular} evens-Swan ... Animals Animal Rig... Regional NY arity: water International Developm... International NY obalGiving International Developm... International DC anned Parent... Health Treatment... Regional PA \begin{tabular}{l|l|l|l}
\hline itional Breast... Health & Diseases, ... National & DC
\end{tabular} ernational Ch... International Developm... International MI ICA of Honol... Human Se... Multipurpo... Regional HI y Year $\quad$ Human Se. Multipurpo... International MA verican Instit... Research ... Social and ... National MA \begin{tabular}{l|l|l|l|l}
\hline Ierican Lung ... & Health & Diseases, ... & National IL \\
\hline
\end{tabular} ban Ventures... Communit... Housing a... Regional MN S. Dream Aca... Human Se... Children's ... Regional MD ipps Conser... Environment Botanical ... Regional PA iance for Just... Human an... Advocacy a... National DC \begin{tabular}{l|l|l|l}
\hline ivada Museu... & Arts, Cultur... Museums Regional NV
\end{tabular} \begin{tabular}{l|l|l|l}
\hline ian Access & Religion & Religious ... & International CA
\end{tabular} \begin{tabular}{l|l|l|l} 
TC & Arts, Cultur... & Public Bro... & Regional \\
\hline
\end{tabular} mouth Housi... Communit... Housing a... Regional WA jrld Neighbors International Developm... International OK d-Ohio Foodb... Human Se... Food Bank... Regional $\mathrm{OH}$ \begin{tabular}{l|l|l|l|l} 
iyton Society ... & Arts, Cultur... & Museums & Regional & $\mathrm{OH}$
\end{tabular} \begin{tabular}{l|l|l|l|l}
\hline nice Family ... & Health & Treatment ... & Regional & CA
\end{tabular} International Foreign Ch... International NY \begin{tabular}{l|l|l|l} 
& Diseases, ... National MA \\
\hline
\end{tabular} \begin{tabular}{l|l|l|l|l} 
& Diseases, ... & National & TX \\
\hline od For The P... & International & Humanitari... International & FL
\end{tabular} \begin{tabular}{l|l|l|l|l}
\hline undation for ... & Health & Patient and... Regional W & W
\end{tabular} ncinnati Natu... Environment Botanical ... Regional $\mathrm{OH}$ n Antonio Fo... Human Se... Food Bank... Regional TX lited Way of N... Communit... Fundraising Regional NY mon Youth Fo... Education Other Educ... National IN \begin{tabular}{c|l|l|l}
\hline ine Public Br... Arts, Cultur... Public Bro... Regional ME & Reg \\
\hline
\end{tabular} \begin{tabular}{l|l|l|l} 
:W Jersey Sy... & Arts, Cultur... & Performing... Regional & NJ
\end{tabular} e Heritage F... Research ... Social and ... National DC lumbus Aca... Education Private Ele... Regional $\mathrm{OH}$ riety the Chil... Communit... Fundraising Regional PA Idlife Conser... Animals Wildlife Co... International CA ispice Educat... Human Se... Social Serv... National ME \begin{tabular}{l|l|l|l}
\hline nball Union ... & Education & Private Ele... & Regional \\
\hline
\end{tabular} od for Others Human Se... Food Bank... Regional VA od Bank of th... Human Se... Food Bank... Regional CO ederik Meijer ... Environment Botanical ... Regional MI itional Tropic... Environment Botanical ... Regional HI vat Haviva Ed... International Internation... International NY interey Bay A... Animals Zoos and A... Regional CA lance for Sch... Education Other Educ... National nalFrancis ... Human Se... Homeless ... Regional iyton History Arts, Cultur. Libraries, Regional imal Welfare ... Animals $\quad$ Animal Rig... Regional \begin{tabular}{l|l|l|l}
\hline Imane Societ... Animals & Animal Rig... & Regional \\
\hline
\end{tabular} itional Comm... Religion Religious ... National issanetta Spr... Religion Religious ... Regional racle Flights $\mathrm{f}$. . Health $\quad$ Patient and... National iw York Com... Communit... Communit... Regional \begin{tabular}{lll} 
eedom Institute Health & Treatment ... & Regional \\
\hline
\end{tabular} lifornia Polic... Human Se... Youth Deve... Regional nrickton Cent... Human Se... Social Serv... Regional M

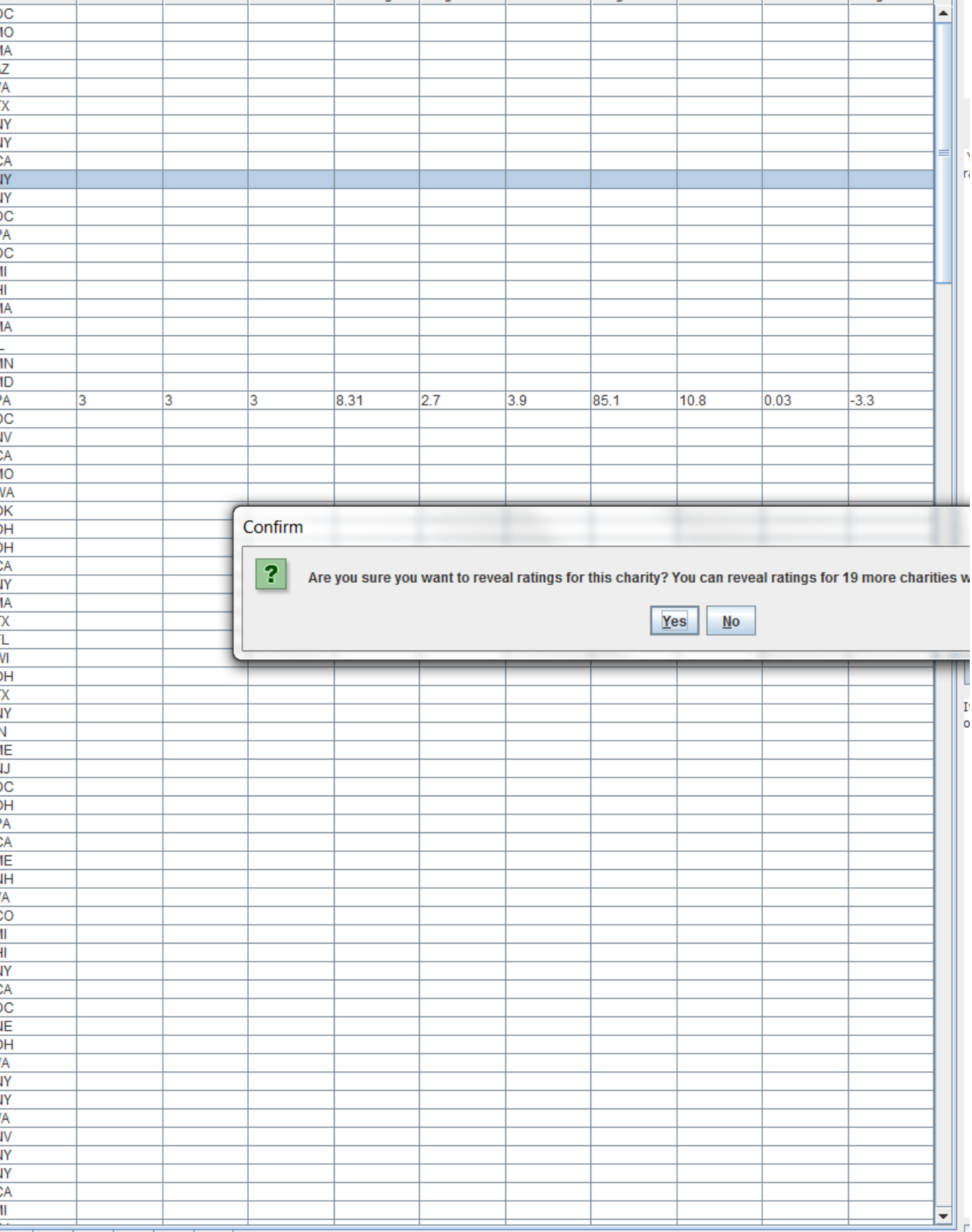

\begin{tabular}{|l|l|l|l|l|l|l|l|l|l|l|l|l|l|l|l|}
\hline 2 & 3 & 4 & 5 & 6 & 7 & 8 & 9 & 10 & 11 & 12 & 13 & 14 & 15 & 16 & 17 \\
\hline
\end{tabular} 
Figure 5: If you choose to "donate using algorithm" you will move to a new screen: You will be able to select a Sector, then Subsector, then Scope, and then, if applicable, a US state (if regional Charity). Below is an example

\begin{tabular}{|c|c|}
\hline \multicolumn{2}{|l|}{ 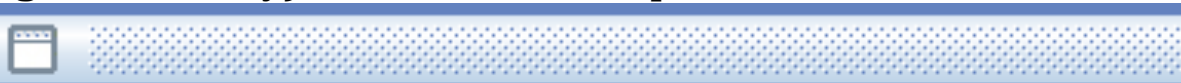 } \\
\hline \multicolumn{2}{|c|}{ Please select a sector, subsector, scope, and state (if applicable). } \\
\hline -- Select a sector -- & $\nabla$ \\
\hline \begin{tabular}{|l}
- Select a sector -- \\
Animals \\
Arts, Culture, Humanities \\
Community Development \\
Education
\end{tabular} & $\Delta$ \\
\hline Ervironment & \\
\hline \begin{tabular}{|l} 
Health \\
Human Services
\end{tabular} & - \\
\hline
\end{tabular}

圅

Please select a sector, subsector, scope, and state (if applicable).

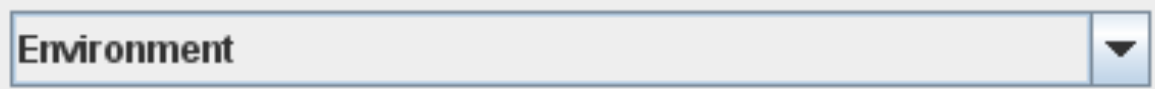

\begin{tabular}{|l|l|}
\hline -- Select a subsector -- & $\boldsymbol{\nabla}$ \\
\hline -- Select a subsector -- \\
\hline Botanical Gardens, Parks, and Nature Centers \\
\hline Ervironmental Protection and Conservation \\
\hline
\end{tabular}

\section{Proceed}

\section{圅}

Please select a sector, subsector, scope, and state (if applicable).

Ervironment

Botanical Gardens, Parks, and Nature Centers

\begin{tabular}{|l|l|}
\hline -- Select a scope -- & - Select a scope -- \\
\hline International \\
National \\
Regional
\end{tabular}




\begin{tabular}{|c|c|}
\hline \multirow{2}{*}{\multicolumn{2}{|c|}{ 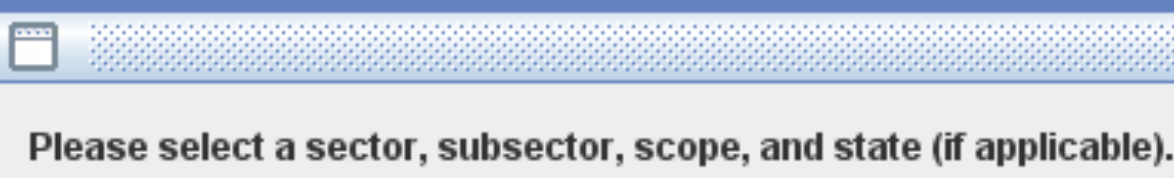 }} \\
\hline & \\
\hline Ervironment & $\boldsymbol{\nabla}$ \\
\hline Botanical Gardens, Parks, and Nature Centers & $\boldsymbol{\nabla}$ \\
\hline Regional & $\nabla$ \\
\hline -- Select a state -- & $\nabla$ \\
\hline MD & $\Delta$ \\
\hline ME & \\
\hline MI & \\
\hline MN & $=$ \\
\hline MO & $=$ \\
\hline NC & \\
\hline NE & \\
\hline $\mathrm{NH}$ & $\nabla$ \\
\hline
\end{tabular}




\section{INSTRUCTIONS: Direct donation Vs. Delegation to $\mathrm{Club}^{2}$}

Your ID number:

Thank you for participating in today's experiment. You've earned a \$5 show-up bonus for participating. In reading and following the instructions below, you have the potential to earn more. In the experiment you will receive Experimental Dollars (E\$s), which will be converted into cash (US Dollars) at the end of the experiment.

The conversion rate from Experimental Dollars (E\$) to cash (US Dollars) is the following: 2 Experimental Dollars (E\$s) are worth 1 US Dollar in cash.

In today's experiment you will be assigned a randomly generated ID number: this ID number will identify your choices in today's experiment. Your ID number is written at the top of this page.

Please note that other participants will not be told your name, and you will not be told their names.

The next section gives a summary description about today's experiment and your task.

2 Instructions for Baseline T1 (direct donation only) and Baseline T3 (Club delegation only) use same wording and include only the relevant sections. 


\section{YOUR TASK:}

You have earned E\$ 40 for participating in today's experiment (excluding show up fee).

In today's experiment you will be given the possibility to donate any amount from $\mathrm{E} \$ 0$ to $\mathrm{E} \$ 40$ of your $\mathrm{E} \$ 40$ to one charitable organization. That charity will receive the amount you chose to donate, and you will keep the rest.

The pool of available charities includes about 5000 non-profit organizations rated by Charity Navigator.

Charity Navigator is an independent American non-profit organization that evaluates charities in the United States. Charity Navigator provides free ratings of the Financial Health and Accountability \& Transparency of charities, and its stated goal is "to advance a more efficient and responsive philanthropic marketplace in which givers and the charities they support work in tandem to overcome our nation's and the world's most persistent challenges".

A brief description of how Charity Navigator rates charities according to charities' financial health, accountability, and transparency has been handed to you (the other handout called "CHARITY NAVIGATOR'S RATING METHODOLOGY"). You may use it as a reference during the experiment.

\section{HOW TO MAKE YOUR DECISION?}

If you choose to donate a positive amount, your task is to choose a recipient for your donation.

If you do not wish to donate in today's experiment, a "Don't Donate" button will be available and you will not be asked to make such decision.

The list will be shown on a user-friendly computer interface. For each charity, the database reports the following information:

5) What is the sector of activity of the charity (e.g. Health).

6) What is the sub-sector of activity or specific mission of the charity (e.g. for the Health sector, one example is "Patient and Family Support"). The full list of sectors and subsectors is available in the handout "CHARITY NAVIGATOR'S RATING METHODOLOGY".

7) What is the scope of work of the charity (e.g. whether the charity operates nationally, internationally, or in a specific US state).

8) A set of Charity Navigator's ratings and indices of each charity's financial health, accountability and transparency. As explained further, these ratings are not visible at the beginning of the experiment, but you can choose to reveal the ratings and indices of charities of your choice at a fixed cost for you. The cost of revealing ratings depends on which donation method you choose. 
You have 2 alternative methods for making a donation:

1) Donate by directly selecting a charity.

2) Donate via club

As explained further in more details, if you choose to directly select a charity, you will have to select one charity directly from the database. If you choose this method, before making a direct donation you will be able to reveal charities' ratings at a fix cost of $\mathrm{E} \$ 2$, if you want to. If you choose to donate via club, you will be able to reveal charities' ratings at a reduced cost ( $\mathrm{E} \$ 1)$, if you want to, and you will see all charities revealed by other club members, if other members have revealed charities' ratings. Differently from the direct donation method, you will not be able to directly select a charity for your donation, but you will be able to cast a vote (at a cost of $\mathrm{E} \$ 1$ ) for one of the charities revealed by all club members. You can choose not to cast a vote, if you want to. Donations from club members will go to charities that received the highest number of votes, up to 3 charities in total.

Before you decide whether you want to directly select a charity, donate via club, or not donate in today's experiment, you will be given time to familiarize with the database. The time you spend on the database is up to you.

We first describe how you can explore the database, if you wish to do that, and then explain how to you can make your decision between direct donation and donation via club(or no donation).

\section{HOW TO EXPLORE THE DATABASE?}

If you wish to explore the database, or lookup for specific charities you have the following methods.

4) You can use the search box at the top of the interface to search for your charities by name. Similarly to a web search engine, when you type the database "shrinks" to only the charities that contain in their name whatever you have typed. If you delete what you typed, you go back to the full database.

5) You can scroll the database using the scroll bar, and use the tabs at the bottom of the database.

6) You can sort the database by sector of activity of charities, subsector, scope of activity and location. To sort by these variables simply click on the variable's name. You can find the full list of sectors and subsectors in the other handout called “CHARITY NAVIGATOR'S RATING METHODOLOGY”.

\section{HOW TO KNOW THE MEANING OF EACH VARIABLE AND WHAT EACH CHARITY DOES?}

In the computer interface, you can always read the description and definition of every variable (including Charity Navigator's ratings or indices) by simply placing the mouse pointer on the variable's name (the first row of the database): a description and explanation of that variable will appear. Similarly, if you place the mouse pointer on the name of the charity, a description of its stated mission will appear (the first column of the database). 


\section{HOW TO REVEAL CHARITIES' RATINGS (USING DIRECT DONATION)?}

You can choose to reveal the Charity Navigator's ratings and indices of charities of your choice. The database contains Charity Navigator's Overall Ratings, Financial Health-specific ratings, Accountability \& Transparency-Specific ratings, and more detailed indices. The ratings are based on a 0 to 4 stars scale ( 0 is the lowest rating, 4 is the highest), and capture the relative ranking of charities based on their financial health, accountability and transparency performances. In addition to these 3 general ratings, the database contains more specific indices of each charity's activities.

If you want to make a direct donation to a charity and you want to reveal charities' ratings, you can pay a fixed cost of $\mathrm{E} \$ 2$ to reveal all the ratings and indices of (up to) 20 charities of your choice. On the right hand side of the interface you will find a button called "reveal charities' ratings". By clicking the button (and then confirm your decision), you will be able to reveal ratings of (up to) 20 charities. To reveal all the ratings and indices of a charity you can simply click on the name of that charity: a popup window will appear asking you to confirm your decision, and the ratings of that charity will be revealed to you. If you reveal ratings and indices for all 20 charities, but you want to reveal more charities, you can click again on the button "reveal charities' ratings": this will give you (up to) 20 more charities to reveal, at the same fixed cost of $\mathrm{E} \$ 2$.

As you reveal charities' ratings through the database, you may want to have all the charities revealed in one place. To do so, you can click the button "Collect Revealed Charities". This will place all the revealed charities together at the top of the database.

Please note that if you choose to reveal ratings on the direct donation interface, and then you decide to join a club, you will still be charged for the $\mathrm{E} \$ 2$. We next describe how to reveal ratings when you donate via club.

\section{HOW TO REVEAL CHARITIES' RATINGS (ONCE YOU JOINED A CLUB)?}

If you choose to donate via club you will first have to click the button "Donate via club". You will then move to a new screen that has the same appearances of the main interface. Once you reach this screen you will still be able, if you want to, to reveal charities' ratings. The difference with the direct donation is that in this new interface the fixed cost to reveal all ratings and indices of (up to) 20 charities is $E \$ 1$, instead of $\mathrm{E} \$ 2$. As for the case of a direct donation, if you reveal ratings and indices for all 20 charities, but you want to reveal more charities, you can click again on the button "reveal charities' ratings": this will give you (up to) 20 more charities to reveal, at the same fixed cost of $\mathrm{E} \$ 1$. The button “Collect Revealed Charities" will be available also in this interface.

We now describe the two methods you have to make a donation today.

\section{1) Direct donation}

If you choose to donate directly, your decision consists in selecting a charity present in the database. To do so, simply click the line corresponding to that charity (it will 
become highlighted in blue). You can then click the button "Donate to Selected Charity". Note that until you click the button "Donate to Selected Charity" you decision is not finalized, meaning that you can select another charity by clicking on it. Once you have selected and confirmed a charity, you will move to a new screen and select how much you want to donate.

\section{2) Donate via club}

If you choose to donate via club, you can click the button "donate via club" on the main interface. This will move you to a new interface, which looks like the initial interface. The difference is that here you will be able, if you want to, to reveal charities' ratings for (up to) 20 charities at a fixed cost for you of $\mathrm{E} \$ 1$. The procedure is the same as described earlier. Once you have made your decisions about revealing (or not) the charities' ratings, you can click the button "Continue to next Stage". You will then move to a wait screen. The wait screen has a button called "Proceed": once all participants have made their decisions, this button will become clickable.

Once you click "Proceed", you will move to a new screen in which all club members will see all the charities' ratings revealed by all members. Note that you will not be revealed the name or number of other club members, nor who revealed which charity. At this point you will decide whether to cast a vote or not for one of these charities. Casting a vote has a cost for you of $\mathrm{E} \$ 1$. You can vote by clicking on the name of a charity: a popup window will appear to ask you confirm your decision. If you don't want to vote, you can click the button "Proceed without voting" at the bottom of the page. Once you have made your decision, you will move to a second wait screen. As for the first wait screen, a button "Proceed" will become clickable as soon as all participants have made their decisions.

Donations from the club will be made according to the following rule: the charities that received the highest number of votes will receive the money, up to three charities at maximum. This means that if you choose to donate via club, you will not be able to directly select a charity for your donation, but you can cast a vote for a charity if you want to increase the probability that the charity receives donations from the club.

Here is an example: suppose 10 participants join a club, and 8 participants vote. Suppose 4 vote for charity X, 2 for charity Y, and 2 for charity Z. Then charity X will receive $4 / 8$ th of the total donations, charity $Y$ will receive $2 / 8$ th of the total donations, and charity $\mathrm{Z}$ will receive $2 / 8$.

Here is another example: suppose 10 participants join a club, and 2 participants vote, one for charity $\mathrm{X}$ and one for charity $\mathrm{Y}$. In this case each charity will receive $1 / 2$ of total donations.

Here is another example: suppose 10 participants join a club, and only 1 participant votes for charity X. Then charity X will receive all total donations.

Here are two final examples: suppose 10 participants join a club, and no participant casts a vote. Only one charity will be randomly selected among the pool of charities and will receive all donations. If no one voted, and no one revealed any charity, then 
one charity will be randomly selected from the entire pool of charities (the initial pool of 5000).

Once all participants make their voting decision, you will move to a screen that will show which charity/charities will receive donations. You will then choose how much to donate.

Important note: The interface is user friendly: for every decision that involves a cost for you or a final decision (e.g. do not donate, reveal ratings, donate directly, donate via club etc.), a pop-up window will appear asking you to confirm your decision. If you clicked a button by mistake you can always undo your decision. Also note that you can drag all columns (as in Excel), to reveal text in the cells.

\section{HOW DO I GET PAID AND HOW MY CHARITY WILL RECEIVE MY DONATION?}

You will be paid one by one in cash and in private at the end of the experiment.

The ID number you have been randomly assigned today will be used as the name of the donor to make the donation you have selected. When all donations are made, all participants for today's session will receive an email (in BCC) announcing that the receipts of the donations are available. If you want to receive your receipt, simply email us your ID number for today's experiment and/or the charity and amount you have chosen, and we will email you the receipt.

Note that no personal information will be shared in this email, nor your personal information, such as your email address, will be shared with the charity you have selected. Please raise your hand if you have any question.

Please take a moment now to mark on the first page of these instructions the number of participants, as you will need this information in the survey following the experiment.

The next pages in this set of instructions contain snapshots of the interface you will use today. We will now give you few moments to look at these pictures and their description: this will help you better to understand how the program interface works. After that, we will distribute a short comprehension quiz, and you will then be able to start the experiment.

\section{Screenshots}


Figure 1: Main program interface (notice the 5 buttons: "Donate to selected charity"; “Donate through Club"; “Don't donate”; "Reveal charities' ratings"; Collect revealed charities")

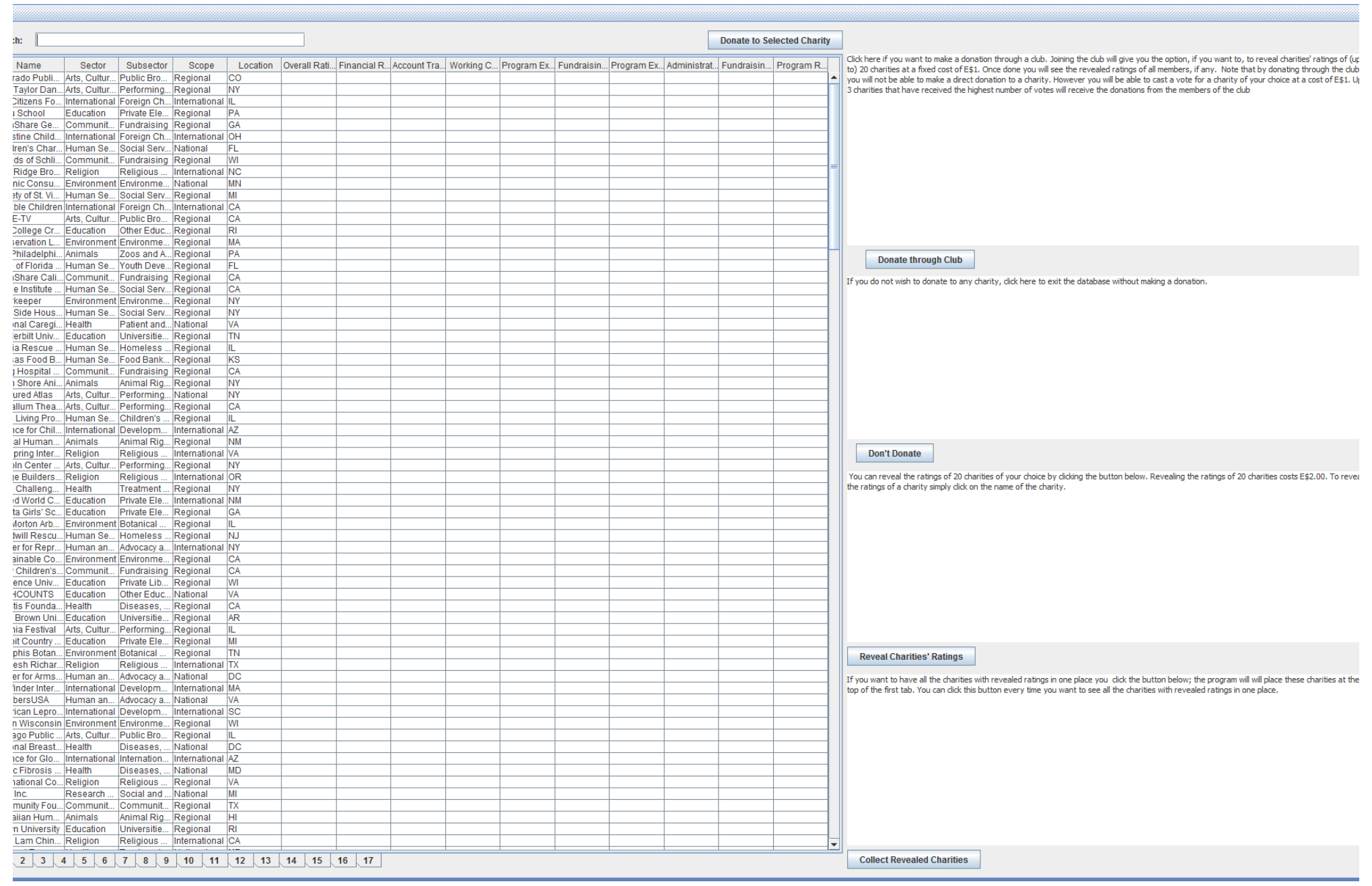

gure 2: Place the mouse on the charity's name and a description of the charity's mission will appear 
arch:

Location Overall Rati Financial R Account Tra Working C Program Ex Fundraisin. Program Ex Administr nazon Conse... Environment Environme... International DC onprofit Lead... Education Other Educ. National \begin{tabular}{l|l|l|l}
\hline ston Ballet & Arts, Cultur... Performing... Regional & MA
\end{tabular} \begin{tabular}{|l|l|l|l|l}
\hline izona-Sonora ... Arts, Cultur... Museums & Regional & AZ \\
\hline
\end{tabular} jina Bifida As... Health $\quad$ Diseases, ... National orldServe Min... Religion $\quad$ Religious ... International TX \begin{tabular}{l|l|l|l} 
ational Jewis... & Religion & Religious ... & International NY
\end{tabular} ie New World ... Communit... Fundraising International NY dependent M... Arts, Cultur.. Public Bro. National CA \begin{tabular}{l|l|l|l|l}
\hline evens-Swan ... & Animals & Animal Rig... & Regional & NY
\end{tabular}

arity: w Founded in 1910, the Stevens-Swan Humane Society (SSHS) of Oneida County provides a balGi safe haven to all domestic pets that must be surrendered, are stray, abandoned, anned homeless, abused, or injured. The SSHS serves as a safe haven for nearly 5.000 animals ational each year that need to be sheltered, regardless of circumstance. Taking care of these ternatil animals 365 days a year is a tremendous responsibility. At SSHS our mission is to protect ICA of Tyear $\mathrm{Y}$. health and safety of both the animals and local communities of Oneida County, New Year York. We make sure that the animals are as comfortable as possible, and that they receive nerical the medical attention they need. We also serve as a source for information for all kinds of nerical animal related problems, questions and help. \begin{tabular}{l|l|l|l|l}
\hline S. Dream Aca... & Human Se... & Children's ... & Regional & MD \\
\hline
\end{tabular} hipps Conser... Environment Botanical ... Regional $_{\text {PA }}$ liance for Just... Human an... Advocacy a... National $\quad$ DC \begin{tabular}{l|l|l|l|l} 
evada Museu... & Arts, Cultur... Museums & Regional & NV
\end{tabular} \begin{tabular}{l|l|l|l} 
sian Access & Religion & Religious ... International CA
\end{tabular} \begin{tabular}{l|l|l|l} 
ETC & Arts, Cultur... & Public Bro... & Regional \\
\hline
\end{tabular} \begin{tabular}{l|l|l|l|l}
\hline ymouth Housi... & Communit... & Housing a... & Regional & WA
\end{tabular} orld Neighbors International Developm... International OK id-Ohio Foodb... Human Se.. Food Bank... Regional $\mathrm{OH}$

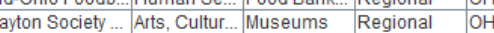
\begin{tabular}{l|l|l|l|l} 
enice Family ... & Health & Treatment ... Regional & CA
\end{tabular} nerica-Israel ... International Foreign Ch... International NY Islin Diabetes... Health Diseases,... National MA ancer Survivor... Health Diseases, ... National od For The P International Humanitari. Internationat FL undation for Health Patientand Regional undation or Healn Patenta... Regional W

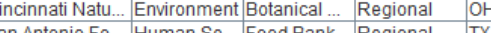
\begin{tabular}{c|c|c|c|c}
\hline an Antonio Fo... & Human Se... & Food Bank... & Regional & TX \\
\hline nited Way of N... & Communit... & Fundraising & Regional & NY
\end{tabular} mon Youth Fo... Education Other Educ... National IN \begin{tabular}{l|l|l|l}
\hline aine Public Br... Arts, Cultur... Public Bro... & Regional ME
\end{tabular} ew Jersey Sy... Arts, Cultur... Performing... Regional NJ e Heritage F Research Social and National Private Ele Regional lumbus \begin{tabular}{|l|l|l|l|l}
\hline Idlife Conser... & Animals & Wild life Co... International CA
\end{tabular} \begin{tabular}{l|l|l|l|l} 
ildife Conser... & Animals & Wild life Co... & International & CA \\
\hline ospice Educat... & Human Se... & Social Serv... & National & ME
\end{tabular} \begin{tabular}{l|l|l|l}
\hline mball Union ... & Education & Private Ele... & Regional \\
\hline
\end{tabular} jod for Others Human Se... Food Bank... Regional VA jod Bank of th... Human Se... Food Bank... Regional $\mathrm{CO}$ ederik Meijer ... Environment Botanical ... Regional MI \begin{tabular}{c|l|l|l|l} 
ational Tropic... & Environment Botanical ... & Regional HI \\
\hline
\end{tabular} ivat Haviva Ed... International Internation... International NY \begin{tabular}{l|l|l|l|l}
\hline onterey Bay A... & Animals & Zoos and A... & Regional & CA \\
\hline
\end{tabular} Onterey Bay A.. Animals Zoos andA. Regio liance for Sch... Education Other Educ... National ena/Francis ... Human Se... Homeless ... Regional NE \begin{tabular}{l|l|l|l}
\hline ayton History & Arts, Cultur... Libraries, ... & Regional & $\mathrm{OH}$
\end{tabular} iimal Welfare ... Animals $\quad$ Animal Rig... Regional umane Societ... Animals Animal Rig... Regional ational Comm... Religion Religious ... National assanetta Spr... Religion Religious ... Regional \begin{tabular}{l|l|l|l}
\hline iracle Flights $f . .$. & Health & Patient and... National \\
\hline
\end{tabular} ew York Com.. Communit. Communit.. Regional \begin{tabular}{l|l|l}
\hline eedom Institute Health & Treatment... & Regional \\
\hline
\end{tabular} \begin{tabular}{l|l|l|l} 
'eedom Institute & Health & Treatment ... & Regional \\
\hline alifornia Polic... & Human $\mathrm{Se} . .$. & Youth Deve... & Regional
\end{tabular} \begin{tabular}{c|l|l|l}
\hline alifornia Polic... & Human Se... & Youth Deve... Regional \\
\hline enrickton Cent... & Human Se... & Social Serv... & Regional
\end{tabular} \begin{tabular}{|l|l|l|l|l|l|l|l|l|l|l|l|l|l|l|l|l|}
\hline 1 & 2 & 3 & 4 & 5 & 6 & 7 & 8 & 9 & 10 & 11 & 12 & 13 & 14 & 15 & 16 & 17 \\
\hline
\end{tabular}

\begin{tabular}{|c|c|c|c|c|c|}
\hline & & & & & Administri \\
\hline & & & & & \\
\hline & & & & & \\
\hline & & & & & \\
\hline & & & & & \\
\hline & & & & & \\
\hline & & & & & \\
\hline & & & & & \\
\hline & & & & & \\
\hline & & & & & \\
\hline & & & & & \\
\hline & & & & & \\
\hline & & & & & \\
\hline & & & & & \\
\hline & & & & & \\
\hline & & & & & \\
\hline & & & & & \\
\hline & & & & & \\
\hline & & & & & \\
\hline & & & & 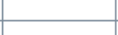 & \\
\hline & & & & 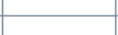 & \\
\hline & & & & & \\
\hline & & & & & \\
\hline & & & & & \\
\hline & & & 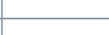 & & \\
\hline & & & & & \\
\hline & & & & & \\
\hline & & & & & \\
\hline & & & & & \\
\hline & & & & & \\
\hline & & & & & \\
\hline & & & & & \\
\hline & & & & & \\
\hline & & & & & \\
\hline & & & & & \\
\hline & & & & & \\
\hline & & & & & \\
\hline & & & & & \\
\hline & & & & & \\
\hline & & & - & 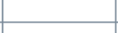 & \\
\hline & & & & & \\
\hline & & & & & \\
\hline & & & & & \\
\hline & & & & & \\
\hline & & & & & \\
\hline & & & & & \\
\hline & & & & & \\
\hline & & & & & \\
\hline & & & & & \\
\hline & & & & & \\
\hline & & & & & \\
\hline & & & & & \\
\hline & & & & & \\
\hline & & & & & \\
\hline & & & & & \\
\hline & & & & & \\
\hline & & & & & \\
\hline
\end{tabular}

gure 3: Place the mouse on the name of any variable and a description and explanation will appear 
!arch:

\begin{tabular}{|c|c|c|c|c|c|c|c|c|c|c|c|c|}
\hline Name & Sector & Subsector & Scope & Location & Overall Rati.. & Financial R.. & Account Tra... & Working C... & Program Ex.. & Fundraisin... & Program Ex.. & $\mathrm{Ad}$ \\
\hline oorways for W... & Human Se... & Social Serv... & Regional & VA & & \multirow{7}{*}{\multicolumn{3}{|c|}{$\begin{array}{l}\text { This is the overall rating of a charity. } \\
\text { The scale is constructed from the } \\
\text { different metrics of financial health } \\
\text { and efficiency, and accountability } \\
\text { and transparency, and goes from } \\
1 \text { (lowest) to } 4 \text { (highest). }\end{array}$}} & & & & \\
\hline range County .. & Communit... & Communit... & Regional & $\mathrm{CA}$ & & & & & & & & \\
\hline nion Rescue ... & Human Se.. & Homeless ... & Regional & AR & & & & & & & & \\
\hline olytechnic Inst... & Education & Universitie... & Regional & NY & & & & & & & & \\
\hline ace University & Education & Universitie... & Regional & NY & & & & & & & & \\
\hline olice Athletic L. & Human Se... & Youth Deve... & Regional & NJ & & & & & & & & \\
\hline ong Island $\mathrm{Ca}$... & Human $\mathrm{Se} . .$. & Food Bank... & Regional & NY & & & & & & & & \\
\hline kansas Sherif.. & Human Se... & Children's ... & Regional & AR & & & & & & & & \\
\hline nited Way of C.. & Communit... & Fundraising & Regional & NM & & & & & & & & \\
\hline nited Way of S... & Communit... & Fundraising & Regional & VA & & & & & & & & \\
\hline terServe USA & Religion & Religious ... & International & $\mathrm{PA}$ & & & & & & & & \\
\hline iends Without.. & International & Foreign $\mathrm{Ch}$... & International & NY & & & & & & & & \\
\hline he Food Bank. & Human Se... & Food Bank... & Regional & LA & & & & & & & & \\
\hline he Museum of.. & Arts, Cultur.. & Museums & Regional & NY & & & & & & & & \\
\hline eorgia Firefig... & Health & Patient and... & Regional & GA & & & & & & & & \\
\hline ational Wome... & Health & Patient and... & National & DC & & & & & & & & \\
\hline revent Cancer . & Health & Medical Re... & National & VA & & & & & & & & \\
\hline enter for Indivi... & Human an... & Advocacy a... & National & DC & & & & & & & & \\
\hline onald McDon... & Health & Patient and... & Regional & NE & & & & & & & & \\
\hline hicago Zoolog.. & Animals & Zoos and A... & Regional & IL & & & & & & & & \\
\hline ational Comm.. & International & Internation... & International & NY & & & & & & & & \\
\hline ctory Ministrie... & Religion & Religious ... & Regional & AK & & & & & & & & \\
\hline he Mr. Holland... & Education & Other Educ... & National & $\mathrm{CA}$ & & & & & & & & \\
\hline hn Wayne Ca... & Health & Medical Re... & Regional & CA & & & & & & & & \\
\hline CFF African Ch... & International & Developm... & International & AR & & & & & & & & \\
\hline reater Mankat... & Communit... & Fundraising & Regional & MN & & & & & & & & \\
\hline omeward Bou... & Communit... & Housing a... & Regional & $A Z$ & & & & & & & & \\
\hline he Food Depot & Human Se... & Food Bank... & Regional & NM & & & & & & & & \\
\hline he Billings Fo... & Human Se... & Food Bank... & Regional & MT & & & & & & & & \\
\hline ovenant Hous.. & Human Se.. & Youth Deve... & Regional & $\mathrm{CA}$ & & & & & & & & \\
\hline ew York Wom... & Human an... & Advocacy a... & Regional & NY & & & & & & & & \\
\hline alvary Childre... & Human Se... & Youth Deve... & Regional & GA & & & & & & & & \\
\hline artners World... & International & Developm... & International & MI & & & & & & & & \\
\hline AME & International & Internation... & International & $\mathrm{CA}$ & & & & & & & & \\
\hline ommission $\mathrm{T}$... & Religion & Religious ... & International & TX & & & & & & & & \\
\hline useum of Fin... & Arts, Cultur... & Museums & Regional & MA & & & & & & & & \\
\hline amestown-Yor... & Arts, Cultur... & Museums & Regional & VA & & & & & & & & \\
\hline he Fresh Air F... & Human Se... & Youth Deve... & Regional & NY & & & & & & & & \\
\hline ternational Co... & Religion & Religious ... & Regional & VA & & & & & & & & \\
\hline MCA of Greate... & Human Se.. & Multipurpo... & Regional & NE & & & & & & & & \\
\hline lanned Parent... & Health & Treatment ... & Regional & $\mathrm{PA}$ & & & & & & & & \\
\hline eague of Con... & Environment & Environme... & National & $\mathrm{DC}$ & & & & & & & & \\
\hline epression an... & Health & Diseases, ... & National & IL & & & & & & & & \\
\hline ity Mission of ... & Human Se.. & Homeless. & Regional & NY & & & & & & & & \\
\hline hildren's Tum... & Health & Medical Re... & National & NY & & & & & & & & \\
\hline lanned Parent... & Health & Treatment ... & Regional & $\mathrm{FL}$ & & & & & & & & \\
\hline 0,000 Degrees & Education & Other Educ... & Regional & $\mathrm{CA}$ & & & & & & & & \\
\hline appa Kappa G... & Education & Other Educ... & National & $\mathrm{OH}$ & & & & & & & & \\
\hline hildren's Diab... & Health & Diseases, ... & Regional & $\mathrm{CO}$ & & & & & & & & \\
\hline anderburgh $\mathrm{H}$... & Animals & Animal Rig... & Regional & IN & & & & & & & & \\
\hline reative Comm... & Research.. & Social and ... & National & $\mathrm{CA}$ & & & & & & & & \\
\hline hofetz Chaim ... & Religion & Religious ... & National & NY & & & & & & & & \\
\hline piscopal Chur... & Religion & Religious ... & International & NY & & & & & & & & \\
\hline stitute for $\mathrm{Hu} . .$. & Education & Other Educ... & Regional & VA & & & & & & & & \\
\hline atin School of ... & Education & Private Ele... & Regional & IL & & & & & & & & \\
\hline abitat for Hum... & Communit... & Housing a... & Regional & $\mathrm{NC}$ & & & & & & & & \\
\hline he Minneapoli... & Communit... & Communit... & Regional & MN & & & & & & & & \\
\hline lashington Ani... & Animals & Animal Rig... & Regional & $\mathrm{DC}$ & & & & & & & & \\
\hline roundSpark & Human an... & Advocacy a... & National & CA & & & & & & & & \\
\hline cademy of Tel. & Education & Other Educ... & National & CA & & & & & & & & \\
\hline
\end{tabular}

gure 4: If you choose to reveal charities' ratings (either on main screen, or once you join a club): To reveal the ratings of a charity, click on the name of the charity (a pop up window will appear asking you to confirm and reminding you how many "reveals" you have left). Below is an example 


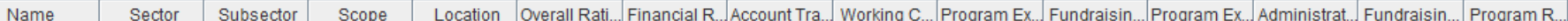
1azon Conse... Environment Environme... International DC inprofit Lead... Education Other Educ... National MO ston Ballet $\quad$ Arts, Cultur... Performing... Regional MA zona-Sonora ... Arts, Cultur... Museums Regional AZ ina Bifida As. Health \begin{tabular}{l|l|l}
\hline rlddServe Min... & Religion & Religious ... International TX \\
\hline
\end{tabular} \begin{tabular}{c|l|l|l|l}
\hline itional Jewis... & Religion & Religious ... & International NY \\
\hline
\end{tabular} e New World ... Communit... Fundraising International NY \begin{tabular}{l|l|l|l} 
jependent M... & Arts, Cultur... & Public Bro... & National \\
\hline
\end{tabular} evens-Swan ... Animals Animal Rig... Regional NY arity: water International Developm... International NY \begin{tabular}{llll}
\hline bbalGiving & International Developm... & International DC
\end{tabular} \begin{tabular}{l|l|l|l|l} 
anned Parent... & Health & Treatment... & Regional & PA
\end{tabular}

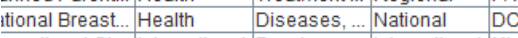
ernational Ch... International Developm... International MI ICA of Honol... Human Se... Multipurpo... Regional HI \begin{tabular}{l|l|l|l}
\hline$y$ Year & Human Se... & Multipurpo... & International MA
\end{tabular} \begin{tabular}{l|l|l|l}
\hline verican Instit... & Research ... & Social and ... National & MA
\end{tabular} verican Lung ... Health $\quad$ Diseases, ... National IL ban Ventures... Communit... Housing a... Regional MN S. Dream Aca... Human Se... Children's ... Regional MD ipps Conser... Environment Botanical ... Regional PA

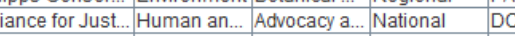
\begin{tabular}{l|l|l|l|l|l}
\hline ivada Museu... & Arts, Cultur... & Museums & Regional & NV \\
\hline ian Access & Religion & Religious & International \\
\hline
\end{tabular} \begin{tabular}{l|l|l|l} 
ian Access & Religion & Religious ... & International CA
\end{tabular} \begin{tabular}{l|l|l|l} 
:TC & Arts, Cultur... & Public Bro... & Regional MO
\end{tabular} mouth Housi... Communit.. Housing a... Regional WA rrld Neighbors International Developm... International OK d-Ohio Foodb... Human Se... Food Bank... Regional $\mathrm{OH}$ \begin{tabular}{l|l|l|l|l}
\hline iyton Society ... & Arts, Cultur... Museums & Regional & $\mathrm{OH}$
\end{tabular} \begin{tabular}{l|l|l|l|l|l}
\hline nice Family ... & Health & Treatment ... & Regional & CA \\
\hline
\end{tabular} verica-Israel ... International Foreign Ch... International NY slin Diabetes... Health Diseases, ... National MA incer Survivor... Health Diseases, ... National TX od For The P... International Humanitari... International FL undation for ... Health Patient and... Regional W ncinnati Natu... Environment Botanical ... Regional $\mathrm{OH}$ in Antonio Fo... Human Se... Food Bank... Regional TX lited Way of $\mathrm{N}$ Communit. Fundraising Regional non Youth Fo... Education Other Educ... National \begin{tabular}{r|r|r|r}
\hline ine Public Br... Arts, Cultur... & Public Bro... & Regional \\
\hline
\end{tabular} \begin{tabular}{c|c|c|} 
iw Jersey Sy... Arts, Cultur... Performing... Regional \\
\hline
\end{tabular} e Heritage F... Research ... Social and ... National Iumbus Aca... Education Private Ele... Regional riety the Chil... Communit... Fundraising Regional \begin{tabular}{l|l|l|l|l}
\hline Idlife Conser... & Animals & Wildlife $\mathrm{C}_{0} . .$. & International CA \\
\hline
\end{tabular} ispice Educat... Human Se... Social Serv... National mball Union ... Education Private Ele... Regional od for Others Human Se... Food Bank... Regional od Bank of th... Human Se... Food Bank... Regional ederik Meijer ... Environment Botanical ... Regional \begin{tabular}{c|ll}
\hline itional Tropic... & Environment Botanical ... & Regional \\
\hline
\end{tabular} vat Haviva Ed... International Internation... International interey Bay A... Animals Zoos and A... Regional iance for Sch... Education Other Educ. National nalFrancis ... Human Se... Homeless ... Regional \begin{tabular}{l|l|l|l}
\hline iyton History & Arts, Cultur... & Libraries, ... & Regional
\end{tabular} \begin{tabular}{l|l|l}
\hline imal Welfare ... Animals & Animal Rig... Regional \\
\hline
\end{tabular} Imane Societ... Animals Animal Rig... Regional itional Comm... Religion Religious ... National issanetta Spr... Religion Religious ... Regional racle Flights $\mathrm{f}$. . Health Patient and... National w York Com... Communit... Communit... Regional \begin{tabular}{l|l|l} 
eedom Institute Health & Treatment ... & Regional \\
\hline
\end{tabular} lifornia Polic... Human Se... Youth Deve... Regional nrickton Cent... Human Se... Social Serv... Regional III

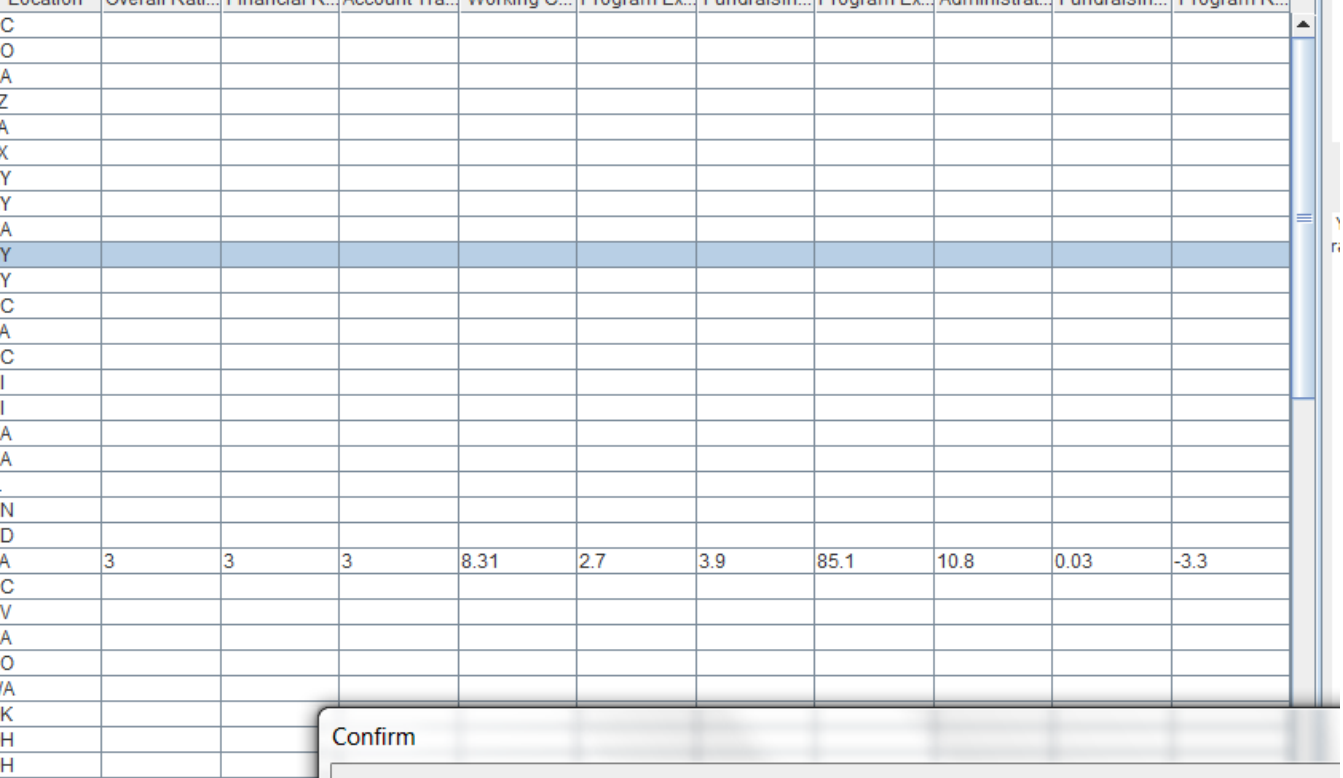

? Are you sure you want to reveal ratings for this charity? You can reveal ratings for 19 more charities w

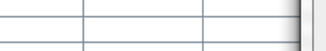

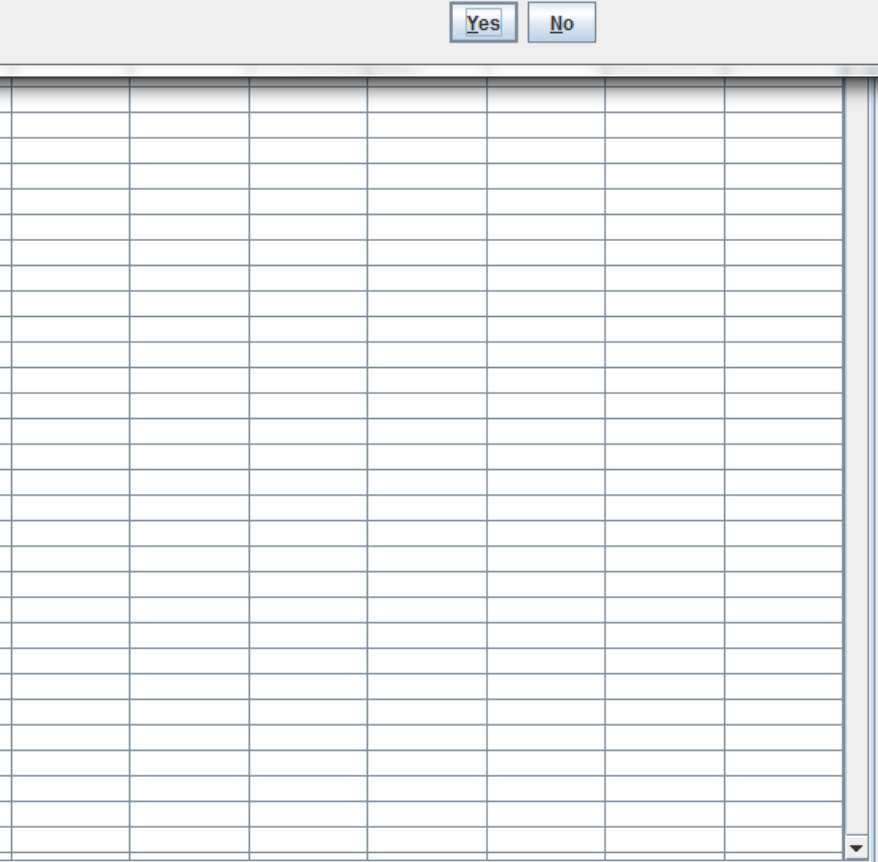

\begin{tabular}{ll|l|l|l|l|l|l|l|l|l|l|l|l|l|l|}
2 & 3 & 4 & 5 & 6 & 7 & 8 & 9 & 10 & 11 & 12 & 13 & 14 & 15 & 16 & 17 \\
\hline
\end{tabular}

Figure 5: If you choose to "donate through club" you will move to a new screen: Notice that the buttons "reveal charities' ratings" and collect revealed charities are available (if you choose to reveal ratings, the fixed cost once you join the club is E\$1). Once you are done with your decision about ratings, you can click the button "continue to next stage" 


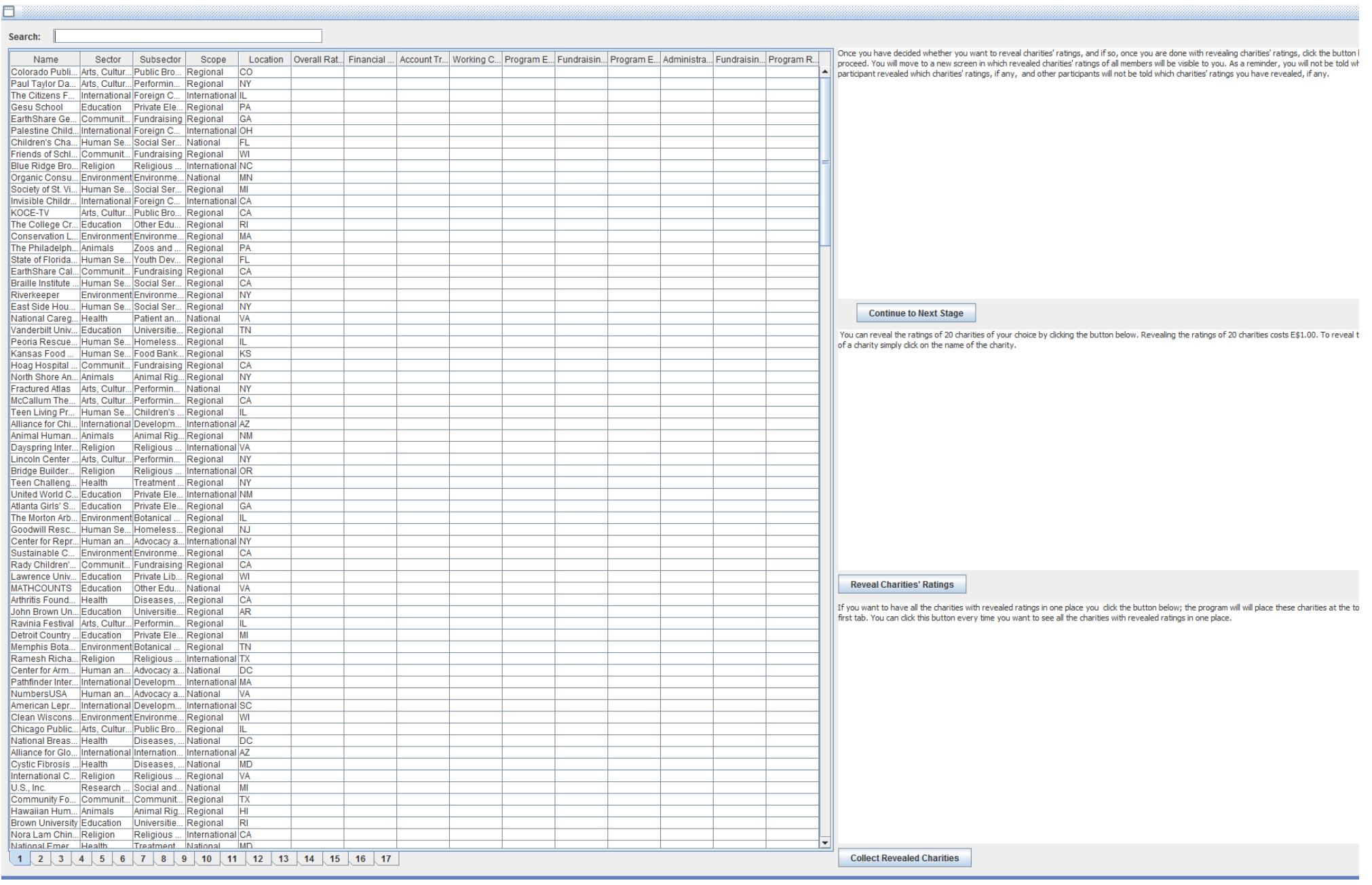

Figure 6: this is the voting screen. All revealed charities, if any, will be shown in a list. If you do no want to vote, you can click the button "Continue without voting" at the bottom of the page. If instead you want to vote for a charity, just click on the charity' name and a popup window will appear to ask you if you want to confirm your decision (as depicted below). 


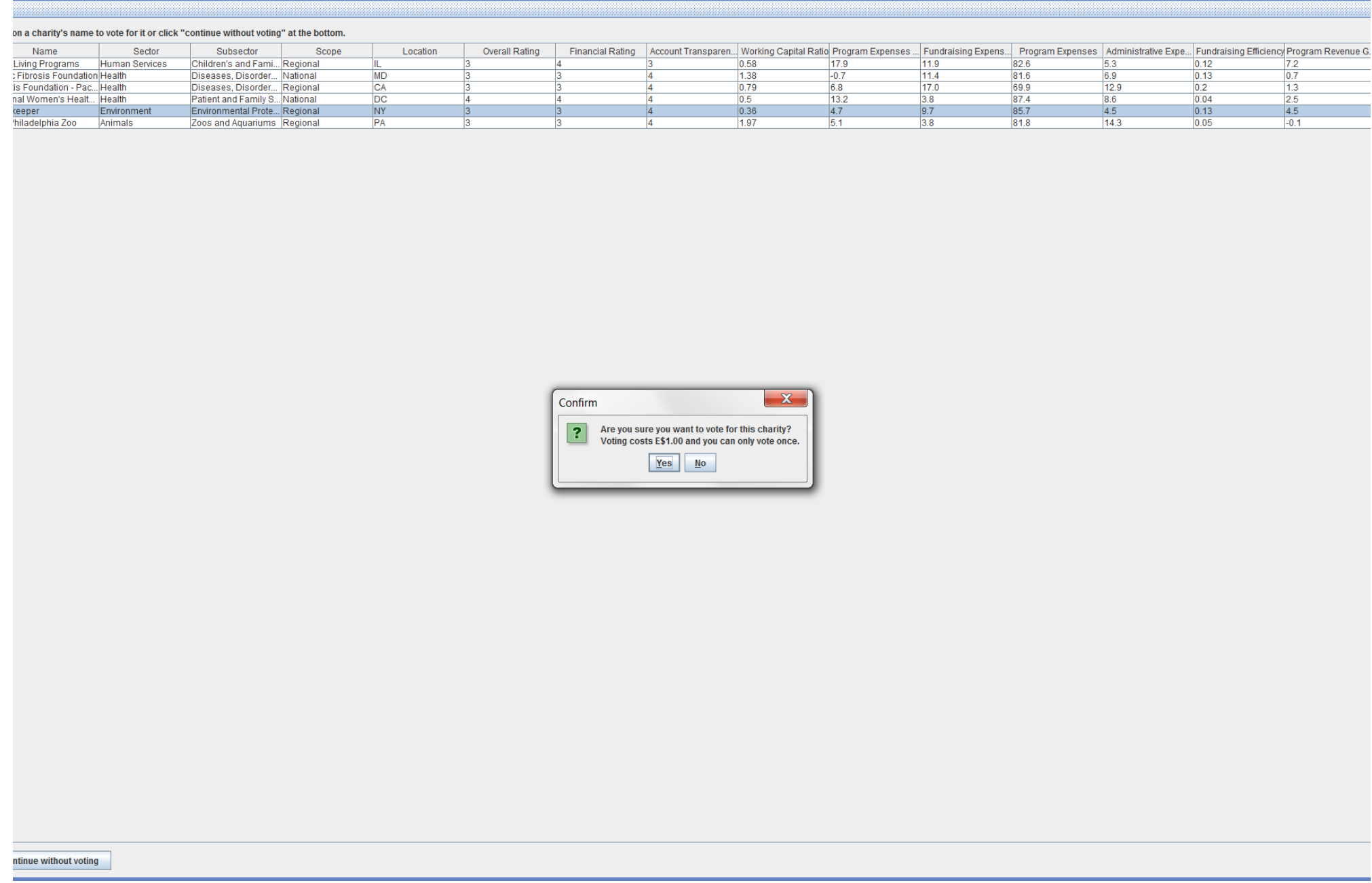




\section{CHARITY NAVIGATOR'S RATING METHODOLOGY (SUMMARY - If you want to learn more visit after the experiment www.charitynavigator.org) ${ }^{3}$}

\section{What kind of charities does Charity Navigator (CN) evaluate?}

Charity Navigator is a national service. It seeks to help as many givers as possible, regardless of where they live or what kind of charity they wish to support. Charity Navigator celebrates and evaluate charities of all types, in all regions of the country, and whose work impacts all corners of the globe.

Tax Status: CN only evaluates organizations granted tax-exempt status under section 501(c) (3) of the Internal Revenue Code and that file a Form 990. 501(c) (3) organizations are considered public charities and all donations to them are taxexempt.

\section{How does $\mathrm{CN}$ classify charities?}

4) General Categories (called Sector in this experiment):

- Animals; Arts, Culture, Humanities; Education; Environment; Health; Human Services; International; Public Benefit; Religion.

5) Causes within each Category (called Subsector in this experiment):

- Animals: Animal rights, Welfare, and Services; Wildlife Conservation; Zoos and Aquariums.

- Arts, Culture, Humanities: Libraries, Historical Societies and Landmark Preservation; Museums; Performing Arts; Public Broadcasting and Media.

- Education: Universities, Graduate Schools, and Technological Institutes; Private Elementary and Secondary Schools; Private Liberal Art Colleges; Other Education Programs and Services.

- Environment: Environment Protection and Conservation; Botanical Gardens, Parks, and Natural Centers.

- Health: Diseases, Disorders, and Disciplines; Patient and Family Support; Treatment and Prevention Services; Medical Research.

- Human Services: Children's and Family Services; Youth Development, Shelter, and Crisis Services; Food Banks, Food Pantries, and Food Distribution; Multipurpose Human Service Organizations; Homeless Services; Social Services.

- International: Development and Relief Services; International Peace, Security, and Affairs; Humanitarian Relief Supplies; Foreign Charity Support Organization.

- Public Benefit: Advocacy and Civil Rights; Fundraising Organizations;

Research and Public Policy Institutions; Community Foundations;

Community and Housing Development.

- Religion: Religious Activities; Religious Media and Broadcasting.

6) Scope of Work: Whether a charity operates nationally, internationally, or in a specific US state.

3 This handout was provided to participants in all treatments. 


\section{How are charities rated?}

$\mathrm{CN}$ rates charities by evaluating two broad areas of performance; their Financial Health and their Accountability \& Transparency. CN ratings show givers how efficiently $\mathrm{CN}$ believes a charity will use their support today, how well it has sustained its programs and services over time and their level of commitment to being accountable and transparent. In the not-too-distant future, $\mathrm{CN}$ plans to also rate charities' reporting of their results. $\mathrm{CN}$ provides these ratings so that givers can make intelligent giving decisions, and so that the philanthropic community can more effectively monitor itself.

\section{How is Financial Health evaluated?}

$\mathrm{CN}$ bases its evaluations on the financial information each charity provides in its informational tax returns, or IRS Forms 990 . CN uses that information to analyze a charity's financial performance in seven key areas that assess its financial efficiency and financial capacity. After analyzing those performance metrics, $\mathrm{CN}$ compares the charity's performance with the performances of similar charities. $\mathrm{CN}$ then assigns the charity a converted score ranging from zero to ten in all performance metrics, as well as a rating for its overall financial health.

The Financial Health of a charity can be described as follows:

1) Charity's ability to manage its finances day by day (e.g. spending less money to raise more; fundraising efforts stay in line with the scope of the programs and services a charity provides; keeping administrative costs within reasonable limits; devoting the majority of their spending to the programs and services they exist to provide).

2) A charity's financial capacity to determine how well it has sustained its programs and services over time, and whether it can continue to do so, even if it loses support or faces broad economic downturns. By doing so, $\mathrm{CN}$ shows givers how well that charity is positioned to pursue long-term, systemic change. Charities that show consistent growth and maintain financial stability are more likely to continue to provide services for years to come. They have the financial flexibility to plan strategically and pursue long-term objectives, rather than facing flurries of fundraising to meet payrolls and other short-term financial obligations. These charities can more ambitiously address our nation's challenges, envisioning and working toward long-term solutions.

\section{How is Accountability \& Transparency evaluated?}

CN defines accountability and transparency in assessing charities as follows:

- Accountability is an obligation or willingness by a charity to explain its actions to its stakeholders.

- Transparency is an obligation or willingness by a charity to publish and make available critical data about the organization.

CN believes that charities that are accountable and transparent are more likely to act with integrity and learn from their mistakes because they want donors to know that they're trustworthy. Generally speaking, charities that follow best practices in governance, donor relations and related areas are less likely to engage in unethical or irresponsible activities. Therefore, the risk that charities would misuse donations 
should be lower than for charities that don't adopt such practices. When examining accountability and transparency, Charity Navigator seeks to answer two basic questions:

- Does the charity follow good governance and ethical best practices?

- Does the charity make it easy for donors to find critical information about the organization?

Some of the factors considered for good governance are the following: Presence of an independent governing board; Absence of material diversion of assets (e.g. absence of unauthorized conversion or use of assets other than for the organization's authorized purposes; Audited financials prepared by independent accountant; Presence of a conflict of interest policy; Ban of loan(s) to or from related parties; Official documents board meeting minutes; Presence of a whist blower policy; Presence of a record retention and destruction policy; Disclosure of CEO and board members' compensations. 


\section{Final post-experiment survey ${ }^{4}$}

-For the following statement, please indicate whether you agree or not: "When I make a donation I generally don't think much about how efficient and accountable the recipient is"

\begin{tabular}{|l|l|l|l|l|}
\hline 1 & 2 & 3 & 4 & 5 \\
\hline $\begin{array}{l}\text { Strongly } \\
\text { Disagree }\end{array}$ & Disagree & $\begin{array}{l}\text { Neither } \\
\text { Agree nor } \\
\text { Disagree }\end{array}$ & Agree & $\begin{array}{l}\text { Strongly } \\
\text { Agree }\end{array}$ \\
\hline
\end{tabular}

-For the following statement, please indicate whether you agree or not: "If no one asked me to, I would never donate to charity"

\begin{tabular}{|l|l|l|l|l|}
\hline 1 & 2 & 3 & 4 & 5 \\
\hline $\begin{array}{l}\text { Strongly } \\
\text { Disagree }\end{array}$ & Disagree & $\begin{array}{l}\text { Neither } \\
\text { Agree nor } \\
\text { Disagree }\end{array}$ & Agree & $\begin{array}{l}\text { Strongly } \\
\text { Agree }\end{array}$ \\
\hline
\end{tabular}

-For the following statement, please indicate whether you agree or not: "You can precisely measure the quality of a for-profit investment, but you it's hard to measure the quality of a non-profit investment"

\begin{tabular}{|l|l|l|l|l|}
\hline 1 & 2 & 3 & 4 & 5 \\
\hline $\begin{array}{l}\text { Strongly } \\
\text { Disagree }\end{array}$ & Disagree & $\begin{array}{l}\text { Neither } \\
\text { Agree nor } \\
\text { Disagree }\end{array}$ & Agree & $\begin{array}{l}\text { Strongly } \\
\text { Agree }\end{array}$ \\
\hline
\end{tabular}

-For the following statement, please indicate whether you agree or not: "Charities should be evaluated based on their impact, and not on how parsimonious they are with fundraising, administrative, and operating expenses. "

\begin{tabular}{|l|l|l|l|l|}
\hline 1 & 2 & 3 & 4 & 5 \\
\hline $\begin{array}{l}\text { Strongly } \\
\text { Disagree }\end{array}$ & Disagree & $\begin{array}{l}\text { Neither } \\
\text { Agree nor } \\
\text { Disagree }\end{array}$ & Agree & $\begin{array}{l}\text { Strongly } \\
\text { Agree }\end{array}$ \\
\hline
\end{tabular}

-For the following statement, please indicate whether you agree or not: "I don't care if the CEO of a non-profit flies in First Class, as far as the non-profit delivers results."

\begin{tabular}{|l|l|l|l|l|}
\hline 1 & 2 & 3 & 4 & 5 \\
\hline Strongly & Disagree & Neither & Agree & Strongly \\
\hline
\end{tabular}

4 This survey was administered to all participants in all treatments. 


\begin{tabular}{|l|l|l|l|l|}
\hline Disagree & $\begin{array}{l}\text { Agree nor } \\
\text { Disagree }\end{array}$ & Agree \\
\hline
\end{tabular}

-For the following statement, please indicate whether you agree or not: "I am more likely to make a donation when a charity solicits me by appealing to my good heart rather than by presenting me with hard evidence of its impact"

\begin{tabular}{|l|l|l|l|l|}
\hline 1 & 2 & 3 & 4 & 5 \\
\hline $\begin{array}{l}\text { Strongly } \\
\text { Disagree }\end{array}$ & Disagree & $\begin{array}{l}\text { Neither } \\
\text { Agree nor } \\
\text { Disagree }\end{array}$ & Agree & $\begin{array}{l}\text { Strongly } \\
\text { Agree }\end{array}$ \\
\hline
\end{tabular}

-For the following statement, please indicate whether you agree or not: "The strongest motivation for people to give to charities is to feel good, not to do some good."

\begin{tabular}{|l|l|l|l|l|}
\hline 1 & 2 & 3 & 4 & 5 \\
\hline $\begin{array}{l}\text { Strongly } \\
\text { Disagree }\end{array}$ & Disagree & $\begin{array}{l}\text { Neither } \\
\text { Agree nor } \\
\text { Disagree }\end{array}$ & Agree & $\begin{array}{l}\text { Strongly } \\
\text { Agree }\end{array}$ \\
\hline
\end{tabular}

-How much effort do you think people exert on finding out how effective charities are before making a donation?

\begin{tabular}{|l|l|l|l|l|l|l|}
\hline 1 & 2 & 3 & 4 & 5 & 6 & 7 \\
\hline No effort & & & & & & $\begin{array}{l}\text { A lot of } \\
\text { effort }\end{array}$ \\
\hline
\end{tabular}

How much effort do you think people exert on finding out how effective charities are after they have made a donation?

\begin{tabular}{|l|l|l|l|l|l|l|}
\hline 1 & 2 & 3 & 4 & 5 & 6 & 7 \\
\hline No effort & & & & & & $\begin{array}{l}\text { A lot of } \\
\text { effort }\end{array}$ \\
\hline
\end{tabular}


